\section{Mieczysław Celestyn Paczkowski OFM}

Uniwersytet Mikołaja Kopernika, Toruń

celestynp@hotmail.com

DOI: http://dx.doi.org/10.12775/BPTh.2015.025

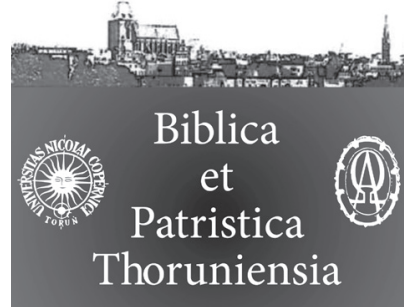

8 (2015) 4: 39-73

ISSN (print) 1689-5150

ISSN (online) 2450-7059

\title{
Przejście Izraelitów przez Jordan (Joz 3-4) w interpretacji patrystycznej
}

\section{The passage of the Israelites across the Jordan River (Joshua 3-4) in the patristic interpretation}

Streszczenie. Artykuł otwiera krótka refleksja na temat typologicznego znaczenia postaci Jozuego i jego dziejów w starożytnym Kościele. Pierwsi chrześcijanie odczytywali księgę Jozuego jako zapowiedź zbawczego dzieła Chrystusa dokonanego na krzyżu. Syn Nuna zajął miejsce Mojżesza jako legislator, natomiast w porządku łaski Zbawiciel zastępuje dawne prawo Ewangelią. Na bazie homonomii Jozue zostaje utożsamiony z Chrystusem: był tym, który wprowadził lud wybrany do Ziemi Obiecanej, stanowiącej jego dziedzictwo. Ojcowie postrzegali ciąg historii Izraela jako odnośnik do życia chrześcijańskiego. W chrześcijańskiej interpretacji biblijnej nie tylko przejście przez Morze Czerwone było typologiczną zapowiedzią chrztu. U niektórych autorów stało się nim także przejście Izraelitów przez Jordan. Ta rzeka była to przecież brama do Ziemi Obiecanej. Następnie analizowana jest kwestia lokalizacji Gilgal. To miejsce odnoszące się do opowiadania o przejściu Jordanu przez Jozuego i rozdzielaniu wód rzeki dotyczy także Eliasza i jego następcy - Elizeusza. Ponadto pojawiła się kwestia chrztu Pańskiego. Typologiczna lektura opowiadania biblijnego nabrała więc nie tylko wydźwięku chrystologicznego, lecz także sakramentalnego. Orygenes z Aleksandrii w obrazie rozdzielonych wód Jordanu dostrzegał dwa rodzaje ludzi przyjmujących chrzest. Jedni to ci, który powracają do dawnego życia i tych którzy pozostają w stanie łasce Bożej. Autorzy wczesnochrześcijańscy dostrzegali także inne wymiary perykopy Joz 3-4, takie jak eklezjologiczny, moralny i duchowy. Ojcowie Kościoła uważali także, że kamienie w Gilgal były zapowiedzią dwunastu apostołów Jezusa. Oni to zostali wezwani, aby stać się szafarzami chrztu i być fundamentami Kościoła. Przez nich zostało ofiarowane przebaczenie grzechów, poznanie prawdy i wejście do „nowej ziemi” obietnic, łaska Boża, działanie niebiańskich darów i łączność z Chrystusem.

Abstract. First of all it is presented a brief reflection on the typological value of the person and work of Joshua in the ancient Church. Christians were reading the Book of Joshua as a foreshadowing of the saving work of Jesus Christ, accomplished on the cross. Joshua replaces Moses as the lawgiver, so the order of grace in Jesus Saviour replaces the ancient order of the Law. On the basis of homonymy Joshua is associated 
with Christ. He was the one who would lead God's people into the Promised Land and and he gave to them the true inheritance. Fathers conceived of the history of Israel as a unique sign announcing the Christian life. For the Christian interpretation, not only the passage through the Red Sea was a typological form of baptism, but so it was also the Israelites' crossing of the Jordan River. It was the gateway to the Promised Land. Aver it is analyzed the problem of topographical location of Gilgal. The location fits well with the biblical narratives relating the crossing of Jordan River by Joshua and the parting of the waters by both Elijah and his successor Elisha. The Jordan River was tied with the baptism of the Saviour. The typological reading of the biblical narrative in question takes on sacramental and Christological characteristics. Origen of Alexandria saw the divided waters of the Jordan as a symbol of two kinds of people who seek Christian baptism: those who turn away from their old lives and remain in God's grace and those who returned to their old sinful habits. The early Christian writers saw the other dimensions of the narrative of Joshua 3-4, that it is ecclesial, sacramental, moral and spiritual. The Fathers of the Church saw the memorial stones in Gilgal as a foreshadow of Jesus' twelve Apostles. They were called to become the ministers of Christian baptism and the foundation stones of the Church. In it is offered instead the forgiveness of sins, the knowledge of the truth, the entry in the new earth, God's grace, the legacy of heavenly goods, union with Christ.

Słowa kluczowe: Jozue (księga); Jordan rzeka (przejście przez); typologia, egzegeza patrystyczna.

Keywords: Joshua (book of); Jordan River (passage across); Typology, Patristic exegesis.

$7 \mathrm{O}$, że księga Jozuego stanowi zagadkę, jest chętnie powtarzane przez współczesnych egzegetów ${ }^{1}$. Nie jest to bynajmniej nowe twierdzenie. Już Ojcowie Kościoła, wyróżniający się przecież poczuciem tajemnicy, w tej księdze biblijnej dostrzegali wiele motywów chrześcijańskiej teologii i duchowości. Tak było również w przypadku trzeciego i czwartego rozdziału. To te rozdziały tworzą pierwszą zwartą całość narracyjną i tematyczną księgi Joz ${ }^{2}$. Przejście Izraelitów przez Jordan to kluczowy moment dziejów Jozuego i zdobycia Kanaanu ${ }^{3}$. Naród Wybrany staje się wówczas świadkiem odnowienia cudów dokonanych nad

1 Por. L.D. Hawk, Every Promise Fulfilled, s. 24.

2 Odnośnie do Joz 3-4 por. E. Vogt, Die Erzählung vom Jordanübergang, s. 125-148; F. Langlamet, La traversée du Jourdain, s. 7-38; J. Dus, Die Analyse zweier Ladeerzählungen des Josuabuches (Jos 3-4 and 6), Zeitschrift für die alttestamentliche Wissenschaft 72 (1960), s. 107-134; B. Peckham, The Composition of Joshua 3-4, s. 413-431.

3 Por. A. Mello, Il passaggio del Giordano, s. 9-12. 
Morzem Czerwonym (por. Wj 14,5-31) ${ }^{4}$. Arka Przymierza, niesiona przez kapłanów, powstrzymuje wody Jordanu, aby lud mógł przejść suchą nogą do kraju obietnic (por. Joz 314-17). Dwanaście kamieni, wydobytych z łożyska rzeki, ułożono w Gilgal jako znak upamiętniający to niezwykłe wydarzenie (Joz 4) ${ }^{5}$. Do Ziemi Obiecanej weszło nowe pokolenie, oczyszczone z grzechów, jakie popełnili przodkowie w „ziemi niewoli”. Pisarze wczesnochrześcijańscy ze swoim szczególnym wyczuleniem na znaczenie tekstu biblijnego znakomicie rozumieli ten historyczny przełom w dziejach narodu wybranego: wejście do ziemi obiecanej Patriarchom, osiągnięcie celu długiej wędrówki z Egiptu i przejście do nowego sposobu życia. Starożytni egzegeci z pewnością nie zdawali sobie sprawy z długiej historii redakcji tekstu Joz, w której dochodziło do łączenia nie tylko różnych przekazów, ale także perspektyw i celów ${ }^{6}$. Tak więc niemal automatycznie pisarze wczesnego Kościoła kojarzyli rzekę Jordan z chrztem Chrystusa u początków głoszenia Królestwa Bożego (por. Mk 1,1-15) ${ }^{7}$.

\section{Biblijne Gilgal (Galgala) i jego identyfikacja}

W Starym Testamencie zawsze wskazywano na rzekę Jordan jako na wschodnią granicę ziemi Kanaan ${ }^{8}$. Potwierdza to zwięzła informacja zawarta w Onomastykonie Euzebiusza z Cezarei ${ }^{9}$. „Jordan, który oddziela Judeę, Arabię i Aulon (dolinę Arabah)... płynie aż do Morza Martwego i po [pokonaniu] wielu zakoli w okolicach Jerycha, wpada do [tegoż] Morza" ${ }^{\prime 0}$.

Jordan od początku był postrzegany jako wyjątkowa rzeka. Orygenes łączył cechy świętej rzeki z jedynością Boga Ojca. „Ponieważ nikt nie jest dobry tylko Jedyny, Bóg Ojciec tak i wśród rzek, żadna nie jest dobra, tylko Jordan"11.

4 Odwołanie do „początku” sugerowałoby także aluzję do Rdz 1, gdy Bóg rozdziela wody, by ukazała się sucha ziemia.

5 Por. R.L. Hubbard, „What Do These Stones Mean”?, s. 1-26.

6 Na ten temat por. np. J.L. Sicre Diaz, Giosuè (Commenti biblici), s. 103-106, 119-124.

7 Zob. również Mt 3,13-17; Łk 3,21-22; J 1,30-34.

8 Por. P. Kaswalder, La terra della promessa. Elementi di geografia biblica, s. 98-99.

9 Biskup Cezarei napisał dzieło, mające służyć pielgrzymom do Ziemi Świętej, w którym przytacza nazwy i lokalizację miejsc wymienionych w Biblii. Około 390 r. dzieło Euzebiusza zostało przetłumaczone na język łaciński przez Hieronima. Nie było to jednak jedyne tłumaczenie Onomastikon, gdyż znana jest jeszcze jego wersja syryjska oraz wersje w innych językach. Por. E. Klosterman (wyd.), Eusebius. Das Onomastikon der biblischen Ortsnamen; T.D. Barnes, The composition of Eusebius' Onomasticon, s. 412-415.

10 Onomasticon 105, 16-18.

11 In Joannem VI,47. 
To dlatego Jordan jest dla Aleksandryjczyka wielką tajemnicą, rzeką - symbolem, a jednocześnie miejscem wielu wydarzeń zbawczych ${ }^{12}$. Z kolei Tertulian przytacza opinie niektórych heretyków o niewystarczalności chrztu dla osiągnięcia życia wiecznego, by tym dobitniej ukazać konieczność chrztu do zbawienia ${ }^{13}$. O wodzie pisze w następujący sposób: „Wszystkie przeto wody w przywileju pierwotnego pochodzenia, po wezwaniu Boga osiągają tajemniczą moc uświęcania. Natychmiast bowiem zstępuje Duch z nieba i przebywa nad wodami i uświęcając je sobą samym, a w ten sposób uświęcone wchłaniają w siebie moc uświęcania"14.

Cyryl Jerozolimski łączył symbolikę wody z Jordanem jako figurą chrztu. „Woda jest czymś wielkim i z czterech widzialnych elementów ${ }^{15}$ jest czymś najpiękniejszym... Początkiem ziemi jest woda i początkiem Ewangelii Jordan... Uwolnienie od grzechów świata odbywa się przez wodę w połączeniu z Bożym słowem... Chrzest jest końcem Starego i początkiem Nowego Testamentu"16.

Według Grzegorza z Nyssy tylko Jordan „otrzymał pierwsze owoce uświęcenia i błogosławieństwa”, jak również tylko on „rozlewa łaskę chrztu na cały świat, jakby z jednego źródła"17. Jordan stanowi więc dla Nysseńczyka typ sakramentu chrztu, lecz lektura chrześcijańska połączona jest greckim wyobrażeniem Okeanosa, który otacza całą ziemię. Ten element pozwala na podkreślenie powszechności łaski. „Strumień łaski płynie wszędzie - deklaruje Grzegorz z Nyssy. Nie ma swych źródeł w Palestynie, by zniknąć w niedalekim morzu ${ }^{18}$, lecz owa rzeka otacza całą ziemię i ma swe ujście w raju"19. Podobnie homilia należąca do zbioru dzieł przypisywanych Janowi Chryzostomowi, przytacza argumenty świadczące o wyjątkowości Jordanu. „Wypływa [on] z żywych źródeł i kończy [swój bieg] w Morzu Martwym, całe cudowne dzieło Boże znajduje

12 J. Daniélou przedstawia Orygenesa jako mówiącego o „wielkiej tajemnicy Jordanu”. Por. Sacramentum Futuri, s. 238.

13 Por. W. Turek, Tertulian, s. 218.

14 Tertulian, De baptismo 4.

15 Wzmianka o „czterech żywiołach” (ziemia, ogień, woda i powietrze) to ślad wpływów judeochrześcijaństwa na kulturę teologiczną Cyryla.

16 Catechesis III,5-6.

17 In Christi bapt.

18 Są tu elementy topografii palestyńskiej. Nie powinno to dziwić, zważywszy na podróż Grzegorza z Nyssy do Ziemi Świętej (data jest sporna: około 380 r. lub między 381 a 382 r.). Opis tego epizodu przedstawił I. Grego, San Gregorio di Nissa pellegrino in Terra Santa, Salesianum 38 (1976) s. 109-125.

19 De baptismo. 
dopełnienie, bowiem ożywcze wody już nie spływają do martwych"20. Tak więc Jordan został wskazany jako miejsce zbawienia przez zapowiedzi Starego Testamentu, w tym przez Jozuego, który przekraczając tę rzekę wprowadził lud do Ziemi Obiecanej. Wody Jordanu zachowują swoje ożywiające właściwości, co oznacza nową ekonomię zbawienia.

Ciekawa jest interpretacja nazwy pierwszego miejsca postoju narodu wybranego w Ziemi Obiecanej21, którą daje Józef Flawiusz: „Gilgal [Galgala] ${ }^{22}$, czyli «wolność». Przeprawiwszy się bowiem przez rzekę, Hebrajczycy czuli się odtąd wolni zarówno od przemocy Egipcjan, jak i od nędznego życia na pustyni"23. Gilgal nie było jednak zakorzenione głęboko w tradycji żydowskiej24 Według Samarytan Galgala miałaby się znajdować niedaleko Góry Garizim, a więc $\mathrm{z}$ zupełnie innym rejonie Palestyny ${ }^{25}$. Kamienie na brzegu Jordanu czcili także poganie, stąd ich późniejsza nazwa jako „głazy śmiertelnych”26.

Jak wiadomo, zwrócono uwagę na powiązanie między chrztem Jezusa w Jordanie ${ }^{27}$ a wejściem Jozuego do Ziemi Obiecanej ${ }^{28}$. Jednak to już pobożność chrześcijańska pierwszych wieków łączyła położenie pierwszego obozu Izraelitów po cudownym przejściu Jordanu z miejscem chrztu Pańskiego. Nastąpiło swoiste nałożenie się na siebie pamiątek biblijnych, gdy wspominano zarówno wydarzenie opisane w Joz $4,1-18^{29}$ oraz chrzest Jezusa opisany przez

20 In Jordanem fluvium 3. Homilia była przypisywana Sewerianowi z Gabali (Marx), chociaż nie brakowało w związku z tym wątpliwości (np. Altendorf). Por. S. J. Voicu, Sévérien de Gabala, w: red. M. Viller, Ch. Baumgartner i A. Rayez, Dictionnaire de spiritualité ascétique et mystique, kol. 752-763.

21 Na temat tego miejsca por. E. Otto, Gilgal, t. 13, s. 268-270.

22 Hebr. „Gilgal” oznacza „kamienny krąg”. Do tej pory dyskutuje się na temat lokalizacji tego miejsca. Por. V. Fritz, Das Buch Josua, s. 48-49.

23 Antiquitates Judaicae V, 36.

24 Por. jedyna wzmianka w Mi 6,5.

25 Por. Onomasticon 65, 19-21.

26 Por. J.E. Taylor, Christians and Holy Places, s. 321, przyp. 63.

27 Na licznych ikonach Chrztu Chrystusa pojawia się personifikacja rzeki Jordan, wylewająca wodę z amfory. Ta postać jest proweniencji pogańskiej. Por. M. Bielawski, Blask ikon, s. 39.

28 Taką opinię wyraża wspólczesny badacz Harald Sahlin. Por. A. Tronina, Jozue - Jezus. Biblijna typologia Zbawiciela, s. 51.

29 Dwunastu mężczyzn wezwanych przez Jozuego, reprezentujących dwanaście pokoleń Izraela, przechodząc przez Jordan do Ziemi Obiecanej, miało wziąć po jednym kamieniu ze środka rzeki, na pamiątkę przejścia suchą nogą przez Jordan, który rozdzielił się, gdy stanęła w nim Arka Przymierza. Owe dwanaście kamieni Jozue ustawił w Gilgal (por. Joz $4,20)$. 
Ewangelistów. Nic więc dziwnego, że podobnie, jak inne miejsca, także Gilgal i jego pamiątki zostały schrystianizowane ${ }^{30}$. To ostatnie wydarzenie od początku stanowiło powszechnie obowiązujący paradygmat w kwestii pierwszego sakramentu. Jednak przy końcu IV stulecia u wielu autorów wyraźnie widać, że uległo zmianie rozumienie chrześcijańskiego chrztu jako ikony chrztu Jezusa. To raczej śmierć i zmartwychwstanie Jezusa według $\mathrm{Rz}$ 6,3-4³1, co zaczynało coraz bardzo intensywniej oddziaływać na wyobraźnię teologiczną ${ }^{32}$. W każdym razie to Zbawiciel „prowadzi nas od dawnego sposobu życia (politeuma) do nowego" ${ }^{33}$. Należy zaznaczyć, że z powodu łatwości, z którą zejście do wody identyfikowano z zejściem w śmierć Jezusa, trudniej było utrzymywać chrzest Jezusa jako jedyny i wyłączny paradygmat chrztu chrześcijańskiego. Punkt ciężkości przesunął się z Jordanu na Kalwarię ${ }^{34}$. Niektórzy autorzy unikali eksponowania pewnych zagadnień ze względu na niebezpieczeństwo herezji ${ }^{35}$.

Już w III wieku zaczęto poruszać kwestie topograficzne odnoszące się do Biblii. Orygenes szczegółowo analizował kwestię „Betanii, po drugiej stronie Jordanu, gdzie Jan udzielał chrztu” (J 1,28). Już od czasów starożytnych owa miejscowość nastręczała nie lada problemów egzegetom. Adamancjusz, jak się wydaje, uwierzył zbytnio swoim informatorom. Pisze on między innymi: „Po przybyciu do miejsc (Palestyny) w poszukiwaniu śladów Jezusa, jego uczniów i proroków, doszliśmy do wniosku, iż nie należy czytać (w Ewangelii) «Betania» lecz «Betabara». To dlatego, ponieważ, jak mówi sam Ewangelista, Betania - miejscowość rodzinna Łazarza, Marty i Marii, znajduje się w odległo-

30 Por. Onomasticon 66,5. Podobnie Anonymus Placentinus, Itinerarium 13; Adomnan, De Locis Sanctis 14.

31 Por. J. Słomka, Wczesnochrześcijańskie nazwy chrztu, s. 134.

32 Zejście katechumenów do wody w basenie chrzcielnym po rytach egzorcyzmów przywołuje chrzest Jezusa w Jordanie. Gdy biskup kładzie swą rękę na głowie katechumena, popychając ją i zanurzając w wodzie czyni podobnie jak Jan Chrzciciel zanurzający Jezusa w rzece Jordan. Wszystko to składa się na jeden złożony gest, nacisk położony jest na zewnętrzny obraz. Chryzostom jest przekonany, że w rzeczywistości boskie Słowo prowadzi Jezusa w chwili chrztu. „Ciało Mistrza zostało ochrzczone przez Słowo i przez głos Jego Ojca z nieba, który rzekł: «To jest mój Syn umiłowany» oraz przez objawienie się Ducha Świętego, który zstąpił na Niego"; Catechesis III,13.

33 Jan Chryzostom, Commentarius in Mattheum XII,3,17.

34 Por. K. McDonnell - G.T. Montague, Inicjacja chrześcijańska a chrzest w Duchu Świętym, s. 341; 343.

35 Odczuwano np. echa adopcjonizmu. Wyznawcy tej doktryny posługiwali się chrztem Jezusa, aby udowodnić niższość Jezusa Chrystusa, który był dla nich zwykłym człowiekiem, gdy zstąpił na niego Duch w momencie chrztu, by uczynić go „przybranym Synem Bożym”. Chrzest w Jordanie zaczął więc być utożsamiany z zaprzeczaniem, że Jezus miał boską naturę od pierwszego momentu swego istnienia. 
ści piętnastu stadiów od Jerozolimy. Jordan zaś oddalony jest o około sto osiemdziesiąt stadiów. Natomiast w okolicach Jordanu nie ma żadnej miejscowości o nazwie «Betania». Mówi się jednak, że na wzgórzach przy Jordanie znajduje się «Betabara», gdzie, jak twierdzą, Jan udzielał chrztu”"36. Refleksje Adamacjusza poświadczają to, że przejście Jordanu pod wodzą Jozuego stanowiło figurę sakramentu chrztu, chociaż dopatrywano się tam także nawiązania do faktu wskrzeszenia Łazarza ${ }^{37}$. Należy dodać, że rozważania autora komentarza o położeniu Betanii i Batabary poprzedzają wzmianki o przejściu Izraelitów przez Jordan. Miejsce tego wydarzenia to Galgala ${ }^{38}$ lub Dodekalithon (Dwanaście Kamieni) $)^{39}$.

Anonimowy pielgrzym z Galii w IV wieku mówi o miejscu, w którym „synowie Izraela przenieśli Arkę Przymierza i umieścili dwanaście kamieni, wyjętych z [dna] Jordanu. Jest tam także miejsce, gdzie Jozue, syn Nuna, obrzezał synów Izraela"40. Anonim z Piacenzy (VI w.) wspomina o obrzędach i „rzeczach niezwykłych”, które działy się "nad Jordanem i w miejscu, gdzie został ochrzczony Pan”. Wspomina także o „dwunastu kamieniach” wmurowanych w ścianę Kościoła w Gilgal. Znajdowały się one w bazylice „niedaleko Jerycha. W niewielkiej odległości [od niej] jest równina zwana Polem Pańskim"41. Umiejscowienie kamieni w centralnym miejscu świątyni niewątpliwie było celowe. Chodziło o to, aby ukazać, że to właśnie chrześcijanie są nowym Ludem Bożym i Nowym Izraelem.

W pierwszych wiekach chrześcijaństwa pątnicy docierali do brzegów Jordanu ze świętego miasta, zatrzymując się w Jerychu. Głównym ich celem było wspomnienie chrztu Chrystusa w Jordanie. Dokumenty historyczne zgodnie potwierdzają, iż zanurzenie $\mathrm{w}$ wodach Jordanu, stanowiło powszechną praktykę dewocyjną, swego rodzaju „naśladowanie Jezusa” i wspomnienie Chrztu świętego. Euzebiusz z Cezarei relacjonował, że wielkim pragnieniem cesarza Konstantyna był chrzest w Jordanie ${ }^{42}$. Ta nadzieja władcy jednak się nie speł-

36 In Johannem VI,40. Zob. R. Khouri, Where John Baptized: Bethany Beyond the Jordan, s. 34-43.

37 Myśl tę rozwinął J. Daniélou, Lentrée dans l'histoire du Salut. Bapteme et confirmation, s. 112-117.

38 Określenie LXX. Wg Pwt 11,30 to Gilgol. Por. P.A. Kaswalder, Onomastica biblica. Fonti scritte e ricerca archeologica, s. 276.

39 W literaturze qumrańskiej Gilgal to miejsce, gdzie Torah zostaje wyryta na kamieniach (por. 4QJosh). O świadectwach wielkiego autorytetu osoby Jozuego w gminie esseńskiej zob. E. Tov, The Rewritten Book of Joshua as Found at Qumran and Masada, s. 233-256.

40 Itinerarium Burdigalense 597, 4-6.

41 Anonymus Placentinus, Itinerarium 13.

42 Por. Vita Constantini IV,62. 
niła. Hieronim w swoim łacińskim tłumaczeniu Onomastikonu pisze, że „aż do dnia dzisiejszego (usque hodie)" przybywa nad Jordan wielu wierzących, by się ochrzcić ${ }^{43}$. W dokumentach historycznych pisze się, iż w nurtach Jordanu chrześcijanie ustawili na marmurowej bazie kolumny metalowy krzyż, który przypominał o Chrzcie Pana Jezusa ${ }^{44}$. O tym miejscu wspomina biograf mnichów palestyńskich - Jan Moskos. Uważa on sanktuarium Chrztu Pańskiego „wspanialsze od góry Synaj”. Często, jak opowiadał pewnemu mnichowi we śnie sam Jan Chrzciciel, nasz Pan tam przychodził, aby odwiedzić swego Poprzednika ${ }^{45}$.

W kręgach ascetycznych profesję monastyczną zwano „drugim chrzte$\mathrm{m}^{\text {"46 }}$ i w tym znaczeniu należy odczytywać opowiadanie o Marii Egipcjance. Nad Jordanem święta pustelnica odbyła wędrówkę w odwrotnym kierunku niż naród wybrany: $\mathrm{z}$ zachodniego brzegu na wschodni (teren Zajordania). Tak oto opowiada mnichowi Zozymie o swojej pielgrzymce ku „ziemi pokoju”47: „Usłyszałam daleki głos: «Jeśli przejdziesz ten święty Jordan, znajdziesz pokój»”. Niewiasta rozpoczęła swój szlak zalewając się łzami. „Kiedy już słońce chyliło się ku zachodowi - opowiada dalej Maria - zobaczyłam kościół Jana Chrzciciela, wznoszący się nieopodal Jordanu. Weszłam do tego sanktuarium, a (następnie) zeszłam ku Jordanowi i jego świętą wodą obmyłam ręce i twarz. Następnego dnia rankiem, jeszcze o brzasku, przeszłam na drugi brzeg"48. Dla egipskiej ascetki ziemią obietnicy było nadjordańskie pustkowie, gdzie czekały ją zmagania duchowe ${ }^{49}$.

Mozaikowa mapa z Madaby przedstawia „Ainon, obecnie Sapsafas”. Pierwszy toponim znaczy tyle co „źródło”, a drugi „trzcina”. Przy systematycznych wykopaliskach latem 1995 r. ${ }^{50}$ natrafiono na ślady murów dawnej ławry, a na-

43 Por. De aliquod Palestinae locis; PL 23, kol. 931. W okresie średniowiecza zapomniano o Betanii po drugiej stronie Jordanu. Budowle chyliły się ku upadkowi, a reszty zniszczenia dopełniły wojny i grabieże.

44 Por. Teodozjusz, De situ Terrae Sanctae 20.

45 Por. Pratum spirituale 1.

46 Por. G. Penco, Sulla professione monastica come secondo Battesimo, s. 34-39.

47 Historia tej pustelnicy opisana jest w starożytnych źródłach; Por. Jan Moschos, Pratum spirituale 179; Cyryl ze Scytopolis, Vita Cyriaci 18. Największy wpływ na kult tej świętej wywarła jednak biografia przypisywana Sofroniuszowi. Por. V. Saxer - S. Heid, Maria Egiziaca, NDPAC, t. 2, kol. 3055-3056.

48 Vita S. Mariae Egyptiacae 18.

49 Por. M. Waheeb, The Discovery of Site of St. Mary of Egypt 2004.

50 Inicjatywa miała swój począte, gdy zmarły już franciszkański archeolog o. Michele Piccirillo wspólnie z jednym z członków rodziny królewskiej z Jordanii odwiedzili teren oddalony około $6 \mathrm{~km}$ od Morza Martwego. 
stępnie mozaiki i ceramikę bizantyjską. Potwierdzenie osadnictwa z czasów Jezusa uzyskano odkrywając ceramikę rzymską, charakterystyczne kamienne naczynia żydowskie i cysterny. Okolica, gdzie bierze swój początek dolina Kharrar posiada obfite źródło, co było niezbędnym warunkiem dla powstawania osiedli ludzkich. Według franciszkańskiego archeologa o. Piccirillo tradycja Betabary (Gilgal) i Betanii/Sapsafas da się pogodzić ${ }^{51}$.

\section{Postać Jozuego}

Typologia chrystologiczna postaci Jozuego ${ }^{52}$ bazuje przede wszystkim na zbieżności imion Jozue - Jezus ${ }^{53}$. W sposób pośredni stosuje ją $\operatorname{Hbr}(4,8-14)$. Autor wskazuje jednak na przeciwieństwo: Jozue nie „wprowadził ich do odpoczynku” (Hbr 4,8), a Chrystus „przeszedł przez niebiosa” (Hbr 8,14) ${ }^{54}$. Typologia Jozuego pojawiła się wtedy, gdy już na dobre trwał konflikt chrześcijaństwa $\mathrm{z}$ judaizmem ${ }^{55}$. Teksty rabinackie porównywały Mojżesza do słońca, a Jozuego do księżyca, co jak się wydaje było reakcją na typologię chrześcijańską ${ }^{56}$.

W sposób wyraźny odwołanie do Jozuego jako „typu” Zbawiciela występuje w traktacie przypisywanym Barnabie (ok. 130 r.). Autor wykorzystuje judaistyczną tradycję zmiany imienia „Ozeasz” na „Jozue” ${ }^{57}$. Warto zaznaczyć, że ten fragment stanowi część parafrazy opisu walki Jozuego z Amalekitami

51 Por. M. Piccirillo, Ainon Sapsafas and Bethabara, s. 218-221.

52 Por. K. Bardski, Chrystologiczna interpretacja Księgi Jozuego u Orygenesa, s. 197-202 .

53 Imię „Jozue” (gr. Jezus) nie było rzadkie w starożytnej historii Izraela. Nowy Testament odnosi się do imienia wodza Izraelitów w Hbr 4,8 i w Dz 7,45. Jeden ze współpracowników św. Pawla nazywał się Jesùs (Kol 4,11). Historyk żydowski Jóżef Flawiusz wspomina o około tuzinie osób tego imienia, niezwiązanych z tekstem biblijnym. W tradycji łacińskiej, w celu podkreślenia najwyższej pozycji Jezusa, następcę Mojżesza nazwano Jozuem. Jednak w tradycji greckiej (a w ślad za nią w prawosławiu) pozostawiono przy jedynym brzmieniu tego imienia, nazywając następcę Mojżesza Jezusem, synem Nuna (Nawego).

54 Podobnie arcykapłan Starego Testamentu przechodził do „Świętego Świętych”. Por. również $\mathrm{Ef} 4,10$.

55 Jednak już Septuaginta bardziej akcentowała rolę Jozuego niż tekst hebrajski. Por. J. Moatti-Fine, La Bible d'Alexandrie, t. 6: Jesus (Josue), s. 25-26.

56 Por. A. Tronina, Jozue - Jezus. Biblijna typologia Zbawiciela, s. 49.

57 „Mówi więc Mojżesz do Jezusa syna Nawe, nadając mu to imię w chwili, gdy posyła go dla zbawienia kraju: Weź w ręce księgę i napisz, co mówi Pan: «U kresu dni Syn Boży wyrwie z korzeniami cały dom Amaleka». Oto znowu objawiony w cielesnej zapowiedzi Jezus, nie syn człowieka, ale Syn Boga"; Epistula Barnabae XII, 8. 
(por. Wj 17) ${ }^{58}$. Syn Nuna jest więc zapowiedzią prawdziwego Zbawiciela, Syna Bożego, który „zbawi swój lud od jego grzechów” (Mt 1,21). Epistula Barnabae wskazuje, że przez długi okres czasu egzegeza chrześcijańska Starego i Nowego Testamentu opierała się na antologiach tekstów biblijnych zwanych Testimonia, nie zaś na systematycznych komentarzach ksiąg biblijnych. Poszczególne wersety lub perykopy grupowano według tematyki teologicznej z myślą o głównych wątkach katechezy ${ }^{59}$.

Jeszcze wyraźniejsze są nawiązania do postaci Jozuego w polemice antyjudaistycznej Justyna z Nablus. Apologeta pisze: „Ten, który doprowadził waszych ojców do tej ziemi, został nazwany imieniem «Jezus», a najpierw nazywano go «Joszua». Jeśli bowiem to zrozumiecie, będziecie mogli pojąć, że imię Tego, który powiedział do Mojżesza «gdyż moje imię jest w Nim» brzmiało «Jezus»"60. Justyn zwraca uwagę, że pierwsze litery imienia „Jozue” Mojżesz zapożyczył z imienia Jahwe. „Jezusa [Jozuego], jak już często powtarzałem, tego samego, który nazywał się Auses [Ozeasz], a którego razem z Kalebem wysłano do Kanaan na zbadanie tej ziemi, Mojżesz nazwał Jezusem. Ty zaś nie pytasz o to, dlaczego tak uczynił!... A zatem o Chrystusie nic nie wiesz, a jeśli czytasz, nie rozumiesz". Apologeta wskazuje na niezwykłe rysy tej postaci, odnosząc to do osoby Zbawiciela. Jozue „został wyznaczony na następcę Mojżesza, będąc wówczas jedynym wśród sobie współczesnych, który wyszedł z Egiptu, doprowadził on ludzi, którzy tej chwili dożyli, do Ziemi Świętej; i tak jak on, a nie Mojżesz, doprowadził lud do Ziemi Świętej. Tak też Jezus Chrystus zbierze znów rozproszonych z ludu i każdemu przekaże dobrą ziemię, choć nie w taki sam sposób. Tamten pierwszy bowiem dał im dziedzictwo doczesne..., ale ten Drugi, po swoim świętym zmartwychwstaniu przekaże nam wieczną własność. Ów pierwszy, gdy przyjął imię Jozue i gdy otrzymał Jego Ducha, sprawił, że słońce stanęło nieruchomo... Był to Jezus, który się objawił i rozmawiał z Mojżeszem i Abrahamem, i z wszystkimi innymi patriarchami bez wyjątku, wypełniając wolę Ojca"61. W otwartej polemice apologeta udowadnia, że Jozue był większy od Mojżesza, który dla Żydów nie miał sobie równych ${ }^{62}$.

58 Por. Epistula Barnabae XII 8-9. Już w judaizmie Amalekici symbolizowali moce diabelskie.

59 Systematyczne komentarze pojawiają się dopiero w czasach Hipolita i Orygenesa. Z czasem kolekcje tekstów biblijnych uzupełniano o sposób interpretacji.

60 Justyn, Dialogus cum Tryphone 75. Zob. także 89.

61 Dialogus cum Tryphone 113. Por. G. Otranto, La tipologia di Giosué nel „Dialogo con Trifone ebreo" di Giustino, s. 29-48.

62 Poza oficjalnym rabinizmem postać Jozuego była wręcz gloryfikowana. Filon z Aleksandrii uwydatnia, że zmiana imienia z Ozeasz („Zbawiony”) na Jozue („Zbawie- 
Jak się wydaje w polemice $\mathrm{z}$ gnostykami postać Jozuego nie odgrywała kluczowej roli, jak w dyskusjach z Żydami. Ireneusz z Lyonu rozważa dzieje syna Nuna w spokojnym kontekście katechetycznej nauki Demonstratio. Mojżesz zmienił jego imię i „nazwał go imieniem Jezus. I tak wysłał go w mocy tego imienia wierząc, że będzie ich mógł przyjąć na powrót ocalonych, gdyż prowadziło ich to imię. I tak się też stało"63.

Dla Orygenesa czyny Jozuego były zapowiedzią zbawczych dzieł Chrystusa. Zbieżność imienia skłania Aleksandryjczyka do tego, by księgę o następcy Mojżesza odczytywać jako proroctwo o Panu Jezusie „Księga Jozuego - pisał Adamancjusz - nie tyle opowiada o czynach syna Nawego, co raczej maluje nam tajemnice dotyczące [...] Jezusa"64. Sens imienia Jozuego był zrealizowany i urzeczywistniony podjętymi przez niego działaniami w harmonijnej współpracy z Bogiem. Historia syna Nuna jest więc rodzajem praeparatio evangelica remota. Osią refleksji Orygenesa nad postacią Jozuego jest typologia historyczna, skupiona na odniesieniach Jozue - Jezus Chrystus. Chodzi zarówno o perspektywę horyzontalną (obietnice i ich wypełnienie), jak wertykalną (rzeczywistość ziemska stanowi cień rzeczy nadprzyrodzonych). Lektura orygenesowska postaci następcy Mojżesza ma ponadto dwa inne wymiary: eklezjalny (sakramenty i życie wspólnoty) oraz indywidualny (walka duchowa i zwycięstwo nad grzechem ${ }^{65}$. Linie tematyczne splatają się z sobą tworząc także całą gamę zagadnień pochodnych ${ }^{66}$. Wiodącym wątkiem jest u Adamancjusza kwestia wyższości Zbawiciela nad Jozuem. Nie ulega wątpliwości, że to sam Bóg ukazał wyższość syna Nuna. Jozue nakazał obrzezanie, które było zapowiedzią prawdziwego znaku chrztu. „Chrystus zajął miejsce Mojżesza, tym, który posiada pierwszeństwo nie jest Jozue, syn Nuna, lecz Jezus, Syn Boży”67. Jozue jest więc „pierwotypem Jezusa Chrystusa, który przez głoszenie nauki ewangelicznej stał się następcą w zarządzaniu Prawem"68.

nie Pana”) ma wyrażać cechę wieczną i doskonałą, przewyższającą śmiertelnego człowieka (zob. De mutatatione 121-122). Podobnie Józef Flawiusz kreśli obraz Jozuego jako dzielnego dowódcy, który również w czasach pokoju był „rządcą niezwykle zręcznym” (Antiquitates Judaicae V, 36). Wg Liber Antiquitatum Biblicarum Pseudo-Filona (koniec I w. po Chr.), Jozue to natchniony duchem proroczym następca Mojżesza (por. A. Tronina, Jozue - Jezus. Biblijna typologia Zbawiciela, s. 49).

63 Demonstratio 27. Biskup Lyonu przywołuje Lb 13,23-24.

64 Homiliae in Jos. I,3. Homileta odwołuje się do Wj 17,8-13 i Kol 2,14-15.

65 Por. R. Scognamiglio, Giosue (scritti esegetici su), s. 197.

66 Por. A. Jaubert (wyd. i tłum.), Origène. Homélies sur Josué, s. 44-46.

67 Homiliae in Jos. II,1.

68 In Johannem $\mathrm{V}, 43$. W oryg. oikonomia (zbawcze dzieło Boże). 
Podobnych informacji dostarcza Tertulian, lecz już w innym kontekście: chodzi o polemikę z Marcjonem i jego kontynuatorami69. Afrykańczyk pisze: „Na następcę Mojżesza ustanowiono Ausesa [Ozeasza], syna Nuna i zaczęto go nazywać imieniem Jezus... To imię było wpierw figurą przyszłego imienia. Bo Jezus Chrystus miał wprowadzić drugi naród, którym my jesteśmy jako urodzeni na pustyni świata, do ziemi obietnic, mlekiem i miodem płynącej, to jest do osiągnięcia życia wiecznego... To miało dokonać się nie przez Mojżesza, to jest przez karność Prawa, ale przez Jezusa czyli przez łaskę Ewangelii”70. Wysłannik Boży został nazwany Jezusem „ze względu na tajemnicę Jego przyszłego imienia"71. Jego czyny wpisywały się w ciąg wydarzeń zbawczej historii. Tak oto przy przejściu przez Jordan płaszcz Eliasza ${ }^{72}$, „był jak miecz rozcinający fale. Również Jozue nauczył proroków przeprawiających się przez Jordan zatrzymać jego bieg i prąd"73. W przypadku Jozuego, jak się wydaje, pisarze chrześcijańscy odstąpili od tradycyjnej typologii dotyczącej Starego Testamentu i judaizmu ${ }^{74}$.

W epoce ponicejskiej typologia postaci Jozuego była już wyraźnie ustalona. Świadczą o tym cykle ikonograficzne, w których typologia Jozue - Jezus zostawiła bogate ślady ${ }^{75}$. W mozaikowej dekoracji rzymskiej bazyliki Matki Bożej Większej pojawiają się sceny dotyczące Jozuego. Syn Nuna jawi się na nich jako wódz porównywalny z rzymskimi wodzami i cesarzami. Służy temu przedstawianie go według schematów ikonografii cesarskiej. Ułatwia to fakt, że Jozue to imiennik Jezusa i jeden z najważniejszych typów Zbawiciela w Starym Testamencie ${ }^{76}$.

69 Autor Adversus Marcionem poświadcza, że marcjonizm był ruchem skrajnie niebezpiecznym, gdyż burzył podstawy ciągłości Boskiego zamysłu zbawienia i pomniejszał wartość Prawa danego w Starym Testamencie. W opinii Ireneusza z Lyonu Marcjon nie tylko odrzucał cały Stary Testament, lecz również „przekonywał swoich uczniów, że jest bardziej prawdomówny od apostołów, którzy przekazali Ewangelię" (Adversus haereses III,3,1). Por. R. Grant McQueen (wyd.), Irenaeus of Lyons. Against Heresies.

70 Adversus Marcionem III,16,4. Por. A. Kroymann-E.Dekkers-J.G.Ph. Borleffs-J.H. Waszink (wyd.), Quinti Septimi Florentis Tertulliani opera, pars I, t. 1; W. Myszor (wstęp i przyp.) - S. Ryznar (tłum.), Tertulian. Przeciw Marcjonowi.

71 Adversus Marcionem III,16,5.

72 Już u początków chrześcijaństwa mówiono o Eliaszu jako wzorze dla wiernych. Por. Klemens Rzymski, Epistula ad Cor. 17,1.

73 Adversus Marcionem IV,20,2.

74 J. Daniélou, Sacramentum Futuri, s. 203.

75 L. Reau, Iconographie de l'art chrétien, t. 2: Iconographie de la Bibles, s. 219-227.

76 Por. S. Adamiak, Sześcioksiąg w mozaikach bazyliki Santa Maria Maggiore w Rzymie, s. $177-178$. 
Cyryl Jerozolimski w celach katechetycznych syntetyzuje dzieje tej biblijnej postaci i zestawia je z osobą i dziełem Zbawiciela. Punktem wyjścia jest zbieżność imion.

"Jezus Chrystus ma podwójne imię: «Jezus», bo jest Zbawicielem, «Chrystus», bo jest Kapłanem. Wiedział o tym Mojżesz, największy z proroków... Pod wielu względami, był Jezus, syn Nawego, wyobrażeniem Chrystusa. Zaczął bowiem rządzić ludem nad Jordanem, gdzie i Chrystus po swym chrzcie rozpoczął głoszenie Dobrej Nowiny"77. Biskup Jerozolimy dopełnia ten wywód ${ }^{78}$ i tłumaczy: „ "Jezus» znaczy u Hebrajczyków «Zbawiciel», u Greków «Lekarz» ${ }^{79}$. Jest On lekarzem dusz i ciała, przynosi zdrowie duchom. Uzdrawia cieleśnie ślepych, daje światło duszom"80.

W tradycji syryjskiej Jozue był postacią wzorcową dla ascetów, bowiem "ukochał dziewictwo" 81 . Jednak typologia o charakterze chrystologicznym miała niewątpliwą przewagę. Afrahat tworzy swoisty paralelizm pomiędzy Jozuem a Chrystusem. „Jozue, Syn Nuna był prześladowany, jak był prześladowany Jezus, nasz Zbawiciel... Prześladowały go nieczyste narody [pogańskie], a [Chrystusa] lud bezrozumny. Jozue, syn Nuna odebrał prześladowcom dziedzictwo i oddał je swemu ludowi, a Jezus, nasz Zbawiciel odebrał dziedzictwo Swym prześladowcom i przekazał obcym ludom ${ }^{82}$. Jozue, syn Nuna nakazał, by słońce się zatrzymało i zemścił się na ludzie swych prześladowców, a Jezus nasz Zbawiciel sprawił się słońce zaćmiło się w południe, lud który Go umęczył przez ukrzyżowanie, doznał hańby. Jozue, syn Nuna podzielił dziedzictwo

77 Catechesis X,11.

78 „Dla podzielenia dziedzictwa wyznaczył syn Nuna dwunastu mężów - dwunastu apostołów jako heroldów prawdy posłał też Jezus na świat cały. Tamten, będąc typem Zbawiciela, ocalił ladacznicę Rahab, ponieważ mu uwierzyła (por. Joz 6,25) - prawdziwy Zbawiciel powiedział: «Celnicy i wszetecznice wyprzedzają Was do królestwa Bożego» (Mt 24,2). Za tamtego, który był typem, na sam głos trąb padły mury Jerycha (por. Joz 6,20) - na słowa Jezusa: «Nie pozostanie tu kamień na kamieniu» (Mt 24,2) runęła naprzeciw nas stojąca świątynia żydowska. Wszakże nie ten wyrok był przyczyną jej upadku, lecz grzechy”; Catechesis X,11.

79 W refleksjach chrześcijańskich przywoływano wizerunek Chrystusa - lekarza, opierając się na Mt 9,12 („Nie potrzebują lekarza zdrowi, lecz ci, którzy się źle mają”) i porównaniach medycznych stosowanych przez autorów klasycznych. Wątek ten był popularny w literaturze starochrześcijańskiej (por. np. Ad Diognetum IX,6; Orygenes, Contra Celsum II,67; III,61; In Psalmum 48,2-3).

80 Catechesis X,12. Po przyjęciu katechumenów nazywano ich tymi, którzy „mają być oświeceni” (gr. fotizomenoi). Chrzest był nawyzwany „oświeceniem”.

81 Por. Afrahat, Demonstratio XVIII,7. Także dla Efrema Jozue był przykladem czystości (zob. Oratio de sacerdotio 8).

82 Autor wskazuje na wybranie pogan. 
swojego ludu, a Jezus nasz Zbawiciel obiecał dać ludom krainę życia... Gdy umierał Jozue, syn Nuna, otrzymał [on] świadectwo wobec swego ludu, a Jezus, nasz Zbawiciel, gdy wstąpił [do nieba], otrzymał świadectwo wśród swoich apostołów"83.

Efrem Syryjczyk w zbieżności imion dostrzega wypełnienie się dzieła zbawienia. „Jozue, syn Nuna przypomina słodki aromat ${ }^{84}$. To dlatego nie jesteś zwodzony odnośnie dopełnienia się prawdziwego imienia Jezusa" ${ }^{35}$. Poetyckie porównania wskazują na dopełnienie się planu zbawienia w osobie Chrystusa.

Hilary z Poitiers w sposób równie jednoznaczny rozwija typologię Jozuego: „W samym imieniu Jozue jasno pokazuje się zamysł przyszłej tajemnicy ${ }^{86}$. Gdy bowiem Bóg objawił Mojżeszowi wiele rzeczy i polecił mu, by wszystko urządził na ziemi zgodnie ze wzorcem, który widział na górze, imię Jozue Jezus nadał wodzowi, którego wołano przedtem Auses, a który miał kierować ludem zdążającym do Ziemi Obiecanej... To zaś imię już w planach nieba było przygotowane dla wiecznego Wodza" 87 . Biskup Poitiers mówi o „pierwszym” i „drugim” Jozuem - Jezusie. „Jak bowiem pierwszy stał na czele synagogi, tak drugi stoi na czele Kościoła. Jak pierwszy był wodzem w osiągnięciu Ziemi Obiecanej, tak drugi jest wodzem w dziedziczeniu ziemi ${ }^{88}$... Jak pierwszy jest po Mojżeszu, tak drugi po Prawie. Pierwszy otrzymał polecenie, aby kamiennym nożem wznowić obrzezanie (por. Joz 5,2), Pan, który jest Słowem ostrym $^{89} \ldots$ w sposób duchowy wznowił obrzezanie serca" ${ }^{\prime 90}$.

Hieronim ze Strydonu opisuje natomiast Jozuego jako „figurę Pana, nie tylko w działaniu, ale i w imieniu. Przechodzi on Jordan, burzy wrogie królestwa, dzieli ziemię między naród zwycięski..., kreśli zarysy duchowych królestw Kościoła i niebiańskiego Jeruzalem" ${ }^{91}$. Egzegeta łaciński z właściwą sobie dozą realizmu przedstawił skrótowo czyny następcy Mojżesza, zakładając, że adresa-

83 Demonstratio XXI, 11.

84 Wonności kojarzono nierozerwalnie ze sferą boskości i świętości. Takich porównań używali chociażby Grzegorz z Nyssy (zob. In Canticum 1) i Cyryl Aleksandryjski (por. De sancta et consubstantiali Trinitate 3 ).

85 Hymnus de virginitate 17. Imię „Jezus” identycznie brzmi po syriacku i hebrajsku. Por. Hymni de nativitate I,31.

86 Por. Tertulian, Adversus Judaeos 9.

87 De mysteriis II,2,5.

88 Hilary cytuje Mt 5,4.

89 Seria cytatów i aluzji biblijnych: Hbr 4,12; Ef 2,20 oraz Iz 28,16; Rz 2,29.

90 De mysteriis II,2,6. Por. również Tertulian, Adversus Judaeos 9.

91 Epistula 53,8. Nawiązanie do Hbr 12,22. 
towi listu homonimia i jej znaczenie są znane. Celem Strydończyka była natomiast ukazanie świętości Palestyny ${ }^{92}$ i Jerozolimy jako prefiguracji Kościoła ${ }^{93}$.

Typologiczne znaczenie postaci i imienia Jozuego odsunęło na dalszy plan często wykorzystywany przez Ojców Kościoła motyw exemplum. Postacie Starego Testamentu były przedstawiane jako przykłady do naśladowania, wzory cnót i wiary. Grzegorz z Nyssy kieruje do słuchaczy ekshortację dotyczącą postaci następcy Mojżesza: „Naśladuj Jozuego, syna Nuna. Nieś Ewangelię, jako on Arkę. Pozostaw za sobą pustynię, to jest grzech. Przejdź Jordan. Skieruj się ku życiu według Chrystusa, ku ziemie przynoszącej owoce nadziei i opływającej, wedle obietnicy, w mleko i miód. Wszystkie te rzeczy stanowią zapowiedź (typos) dotyczącą nas. Wszystkie są prefiguracją rzeczywistości, która teraz się objawia"94. Biskup Nyssy przenosi punkt ciężkości z osoby Chrystusa, którego zapowiadał Jozue, na chrześcijanina, który przez chrzest upodobnił się do Niego.

Wśród pouczeń dawanych członkom kleru, Ambroży przypomina przykład Jozuego, towarzyszącemu Mojżeszowi. „Jozue był tak wielkim mężem, ponieważ stałe przebywanie z Mojżeszem nie tylko ułatwiło mu poznanie Prawa, lecz także doprowadziło go do uświęcenia przez łaskę... Był on nieodstępnym towarzyszem świętobliwego Mojżesza" ${ }^{95}$. Biskup Mediolanu obficie czerpie z historii Jozuego, który wiernie posługiwał Mojżeszowi i nie oddalał się od przybytku (por. Wj 33,11). Wzmiankuje zmianę imienia (por. Lb 13,16) i przebywanie na Synaju (por. Wj 24,13) oraz uczestnictwo w duchu prawodawcy narodu wybranego (por. Pwt 34,9). W szerszym znaczeniu chodzi o proces formacji czy towarzyszenia mistrzowi, by uczyć się właściwej postawy i zachowań ${ }^{96}$. Postawa Jozuego ma rysy synostwa duchowego. On sam, podsumowuje Mediolańczyk, „wyrósł na takiego męża, że mógł rzeki wstrzymywać w biegu (por. Joz 3,14-17)"'97.

Trudno jednak znaleźć znaczące przykłady tego typu interpretacji postaci Jozuego w literaturze monastycznej, mimo, że asceci doszukiwali się pierwowzorów swego sposobu życia w Mojżeszu i w prorokach Starego Testamentu ${ }^{98}$.

\footnotetext{
92 Por. wyrażenie „Terra Sancta” z Epistula 109,2.

93 Por. np. In Isaiam III,8,9; In evangelium Matthaei IV (27,52-53).

94 De baptismo.

95 De officiis ministrorum 98.

96 Łacińska księga Ezdrasza przedstawia Jozuego jako wzór modlitwy wstawienniczej „za Izraela, za dni Akana” (4 Ezd 7,107).

97 De officiis ministrorum 99. Aluzje do Joz 10,12-14; 1,2

98 Por. N. Füglister, L'expérience de Dieu dans et selon l'Écriture: le prophète comme un prototype, s. 93.
} 
Synonimem przewodnika duchowego w dokumentach odnoszących się do początków ruchu ascetycznego był „starzec" ${ }^{\prime 9}$. Mnisi czasami powtarzali cuda lub postawę Jozuego ${ }^{100}$. Kluczowe dla mnichów były pokuta i pokora przed Bogiem. „Popatrzmy na Jozuego, syna Nuna - mówił jeden ze starców - gdy upadł na twarz, wtedy objawił mu się Bóg"101.

3. Lektury typologiczne opowiadania biblijnego

Typologia związana ze chrztem świętym była szeroko wykorzystywana przez autorów starożytności chrześcijańskiej. Do najbardziej znaczących i najpopularniejszych motywów dołączano także te wydarzenia, które według opisów biblijnych rozegrały się nad Jordanem. Obok typologii o charakterze topograficznym tworzy się także swego rodzaju łańcuch epizodów, nawiązujących do tajemnic chrzcielnych: przejście przez Morze Czerwone, przekroczenie Jordanu pod wodzą Jozuego, niektóre wydarzenia z życia Eliasza i oczyszczenie $\mathrm{z}$ trądu Naamana ${ }^{102}$. W ten sposób wzmacniał się związek istniejący pomiędzy zapowiedzią, a jej wypełnieniem się w sakramencie. Osnowę teologiczną tych rozważań stanowiło odwoływanie się do „typów”, wyróżnionych już przez apostoła Pawła ${ }^{103}$. Ich lektura chrystologiczna nie wzbudzała najmniejszej wątpliwości. Relacja „figura” - „sakrament” znajdowała swój punkt oparcia w Chrystusie $^{104}$, co również zgadzał się z linią Apostoła pogan.

Bogata symbolika Jordanu była dla autorów chrześcijańskich bardzo kusząca, lecz siła tradycji ${ }^{105}$, która kazała dostrzegać wyłącznie w przejściu przez Morze Czerwone figurę chrztu świętego ${ }^{106}$, była zbyt silna. Temat przejścia Jordanu jako odnośnik do pierwszego sakramentu nie zastąpił mocno ugruntowanej typologii, lecz z nią współistniał. Epizod ten wspomina Ireneusz z Lyonu w kontekście historii zbawienia. Przypomina, że „syn Nuna zajął miejsce [Mojżesza].

99 Abbas, apa, senex, pater, saba, khello, starec. Por. I. Hausherr, Direction spirituelle en Orient autrefois, s. 322.

100 Por. Apophtegmata Patrum (Geronticon) 260, 334.

101 Apophtegmata Patrum XV,57 (kolekcja systematyczna). Aluzja do Joz 5,14.

102 Ta seria wydarzeń wspominana jest w liturgii koptyjskiej i etiopskiej.

103 Por. M. Simonetti, Lettera e/o allegoria, s. 143, przyp. 131.

104 O charakterze chrystologicznym typologii por. J. Daniélou, Qu'est ce que la typologie?, s. 201.

105 Wyjątek stanowił Justyn. Por. Dialogus cum Tryphone 86.

106 O typologii chrzcielnej przejścia przez Morze Czerwone por. J. Daniélou, Traversée de la Mer Rouge et Baptême aux premières siécles, s. 402-430; P. V. van Moorsel, Rotswonder of Doortrocht door de Rode Zee, s. 59-68. 
Rozdzielił Jordan i przeprowadził lud do krainy [Kanaan], a następnie po zniszczeniu siedmiu ludów, które ją zamieszkiwały, podzielił ją między lud"107.

Dopiero Orygenes w sposób zdecydowany akcentował znaczenie Joz 3-4 w interpretacji chrzcielnej. Miejsce przejścia ludu wybranego przez Jordan było bramą do ziemi obiecanej. Aleksandryjczyk opierał się na interpretacji chrztu Jezusa w Jordanie i na antytezie Jozue - Mojżesz. Ukazanie Jordanu jako figury chrztu i wejścia w życie chrześcijańskie ${ }^{108}$, było swoistą tarczą chroniącą skutecznie pierwszeństwo Jozuego względem Mojżesza. Jednocześnie chrześcijański egzegeta rozwiązywał trudny problem interpretacyjny dotyczący walk Izraelitów w ziemi obiecanej pod wodzą syna Nuna ${ }^{109}$. Widać to już w swoistym preludium, jakim była bitwa z Amalekitami. „Skoro przystąpisz do głębi duchowej nauki, spodziewaj się walki i szykuj się do wojny" ${ }^{110}$, głosił Orygenes. Jozue to wybraniec Boży. Mojżesz uosabia Prawo ${ }^{111}$, a ono w ukryty sposób wskazuje na Chrystusa, prosząc Go o wybranie „mocarzy” z ludu ${ }^{112}$. „Mojżesz woła Jezusa, Prawo wzywa Chrystusa”113. Bóg „za pośrednictwem Jozuego (tj. Jezusa) przeprowadził [lud] przez Jordan"114.

U Orygenesa w refleksji nad Joz pojawia się wielokrotnie paradygmat walki duchowej ${ }^{115}$. Jest to wynik stosowania przez Aleksandryjczyka podstawowej

107 Demonstratio 29.

108 O związku Jordanu z obrzędami chrzcielnymi świadczy struktura baptysterium judeochrześcijańskiego w Nazarecie w podziemiach obecnego kościoła św. Józefa. Dno basenu chrzcielnego pokrywa mozaikowa dekoracja w czarne kwadraty na białym tle. W mozaikę wprawiono bazaltowy kamień i wymurowano rowek niemający najmniejszego uzasadnienia praktycznego. Ten element symbolizuje Jordan, przez który przechodził naród wybrany, wkraczając do Ziemi Obiecanej, a ochrzczony na łono Kościoła. Większy kamień to symbol utożsamienia się ochrzczonego z Chrystusem - kamieniem węgielnym. Kwadraty w mozaice to przypomnienie o sześciu aniołach, stanowiących orszak Syna Bożego. Por. B. Bagatti, Excavations in Nazareth, t. 1: From the Beginning till the XII Century (Collectio maior SBF 17), tłum. ang. E. Hoade, Jerusalem 1969, s. 231-232.

109 Por. A. Jaubert, Origène. Homélies sur Josué (SC 71), s. 48-49.

110 Homiliae in Exodum XI,3.

111 Według talmudycznego zapisu „Mojżesz otrzymał Prawo na Synaju i przekazał jeą swemu następcy Jozuemu, Jozue starszym ludu (t.j. przywódcom pokoleń), oni prorokom, a ci mężom wielkiego zgromadzenia (t.j. Sanchedrynowi)"; Miszna Awot 1,1.

112 Por. Wj 17,9. Określenie „mocarz” znajduje się w Septuagincie i brak go w tekście hebrajskim.

113 Homiliae in Exodum XI,3.

114 In Joannem VI,43.

115 Por. Homiliae in Jos. I,7; IX,1; XIII,14 Podobne wątki można znaleźć w komentarzu do Czwartej Ewangelii: „Niewidzialni wrogowie zostaną pokonani, a Izraelici w nas, to znaczy nasze myśli, odniosą zwycięstwo”; Comm. in Johannem XXVIII,5,38. 
zasady metodologicznej, według której należy szukać głębszego sensu tekstu biblijnego ${ }^{116}$. Nie brak przy tym odwołania do etymologii Jordanu. Nie jest to odosobniony przypadek, bowiem w egzegezie alegorycznej dużą rolę odgrywała etymologia nazw miejsc wymienionych na kartach Biblii ${ }^{117}$. Orygenes podkreśla, że nazwa Jordan „znaczy «Ich zstąpienie». Nazwie tej bliskie jest... imię «Jard», które również znaczy «Ten, który zstępuje»... To czym może być rzeka - «Ich zstąpienie», do której powinien przybyć i oczyścić się w niej Ten, który zstępuje?... Czy nie jest nią nasz Zbawiciel, który oddziela tych, co otrzymali dziedzictwo od Mojżesza, od tych, którzy otrzymują własny dział dzięki Jezusowi [t.j. Jozuemu]?... Jordan należy rozumieć jako Slowo Boże, które stało się ciałem i zamieszkało między nami (por. J 1,14), jako Jezusa, który spadkobierczynią swoją uczynił całą ludzką naturę, którą przybrał"118.

Dzięki pogłębionej refleksji egzegetycznej Orygenesa przejście przez Jordan zaczęło w sposób jednoznaczny stanowić figurę sakramentu chrztu. Ponadto wydarzenie to stało się symbolem i „sakramentem” samego Chrystusa, rzeką, która „rozwesela miasto Boże” (por. Ps $46[45], 5)^{119}$. „Należy więc rozumieć przez Jordan Słowo Boże, które stało się ciałem i zamieszkało między nami, a przez Jozuego, który rozdzielił części, człowieczeństwo, które Chrystus przyjął"120. Aleksandryjczyk pojmował chrzest jako zanurzenie w samym Chrystusie, jako spotkanie z Tym, który oczyszcza i uświęca. Adamancjusz w swoich wypowiedziach łączy wydarzenia historii narodu izraelskiego z faktami życia chrześcijańskiego. Tym samym aleksadryjski autor wskazywał na zasadę jedności całego Pisma Świętego. W takim klimacie refleksji nad natchnionym tekstem stało się oczywiste, że ze środowiska aleksandryjskiego wywodzi się

116 Orygenes sformułował następująco tę metodę: „Pan usuwa zasłonę z tekstu Starego Testamentu i swoim sługom, którzy w Niego wierzą, pozwala z odsłoniętym obliczem oglądać chwałę Pana (por. 2 Kor 3,18). Powinniśmy zrozumieć, że to wszystko zdarzyło się jako symboliczna zapowiedź i zostało spisane ze względu na nas, których dosięga kres wieków (por. 1 Kor 10,11). A zatem próbujmy wznosić się od litery do ducha, od symbolicznych zapowiedzi do prawdy". Homiliae in Jos. III,1.

117 Tak było już w przypadku Filona z Aleksandrii, który na tej podstawie przechodził od sensu dosłownego alegorycznego. Nieco odmienna była opinia pisarzy małoazjatyckich, jak chociażby Teofila z Antiochii. Dla niego etymologia stanowiła raczej potwierdzenie interpretacji dosłownej niektórych fragmentów Biblii; por. M. Simonetti, Lettera e/o allegoria, s. 18 i 48, przypis 109.

118 In Joannem VI,42.

119 Motyw „rajskiego miasta” jest obecny Orygenesowskich Homilia in Numeros XVII,4.

120 J. Daniélou, Bible et liturgie. La théologie biblique des sacrements et des fêtes d'après les Pères de l'Église, s. 142-143. 
utożsamianie sakramentu chrztu z rzeką Jordan. Ten element był stałą w rozważaniach autorów greckich, łacińskich i syriackich ${ }^{121}$.

Biblijny obraz przejścia Jordanu służy w formowaniu określeń chrzcielnych. Według Orygenesa chrześcijanin przez chrzest zostaje zanurzony w wodach Jordanu. Przez sakrament chrztu rozdziela te wody ${ }^{122}$. „Możemy wysunąć podobne twierdzenie o tych, którzy przeszli Jordan: wszyscy zostali ochrzczeni w Jozuem w Jordanie, także to, co się wydarzyło w Jordanie, jest zapowiedzią tajemnicy, która się dokonuje na chrzcie"123. Dochodzi tu do głosu zasada jedności Pisma Świętego. Tajemnica chrztu została ukryta w przejściu Izraelitów przez Jordan. Chociaż każdy Izraelita antycypował doświadczenie chrztu, to jednak nie było ono pełne i stanowiło zaledwie cień dóbr duchowych Kościoła i tego, co jest przedmiotem oczekiwań chrześcijanina.

Orygenes mówił wyraźnie o dwóch porządkach chrztu: „Chociaż wszyscy ci bracia zostali ochrzczeni według porządku mojżeszowego, w obłoku i w morzu..., bali się jeszcze wrogów i krzyczeli do Pana. Natomiast chrzest według porządku Jozuego [tj. Jezusowego] w rzece..., jest doskonalszy niż tamten, ponieważ cześć Boża jest jawna i otrzymuje właściwy sobie charakter. Otóż Arka Przymierza Pana Boga naszego oraz kapłani lewici idą na czele (por. Joz 3,14), a lud postępuje za sługami Boga, którzy przestrzegają Jego przykazania czystości (por. Mt 19,12). Jozue zaś mówi do ludu: «Oczyśćcie się, gdyż jutro Pan sprawi cuda wśród was» (Joz 3,5). Kapłanom nakazano iść z Arką Przymierza przed ludem. Objawia się wówczas tajemnica zamierzeń Ojca względem Syna: Ojciec wywyższa Go i udziela Mu łaski, «aby na imię Jezusa zgięło się każde kolano istot niebieskich, ziemskich i podziemnych. I aby wszelki język wyznał, że Jezus Chrystus jest Panem ku chwale Boga Ojca» (Flp 2,10-11). Przez chrzest w Jezusie poznajemy, że Bóg żywy znajduje się pośród nas" ${ }^{124}$.

Aleksandryjczyk zestawia opowiadania z Joz i narrację ewangeliczną. Nowy Testament stanowi wyjaśnienie epizodów opowiedzianych w księdze starotestamentowej. Ma się do czynienia ze zgodnością Pisma i jego harmonią. Orygenes uważał, że „jeżeli Pismo Święte mówi, że jedna część wód Jordanu ucieka do morza i pogrąża się w słonych falach, podczas gdy druga pozostaje słodka (por. Joz 3,16), ma to znaczenie duchowe"125. To przekonanie Orygenesa

121 Por. F.J. Doelger, Der Durchzug durch den Jordan als Sinnbild der christlichen Taufe, s. 74 i 76.

122 Por. Homilia in Jos. IV,1.

123 Homilia in Jos. V,1.

124 Orygenes, In Joannem VI,43-44; w: J. Danielou, Sacramentum Futuri, s. 235.

125 Homilia in Jos. IV,2. Por. M. Spyra, Elementy teologii chrzcielnej w czwartej i piatej homilii Orygenesa, s. 43. 
jest widoczne nie tylko tutaj, ale także w wielu innych częściach komentarza do J. Staraniem egzegety aleksandryjskiego było stwierdzenie istnienia sensu duchowego obok literalnego. „My również prośmy Boga, aby udzielił nam duchowego zrozumienia przejścia przez Jordan, dzięki Jozuemu... Paweł [apostoł] mógł i tym przejściu powiedzieć: Nie chcę, bracia, żebyście nie wiedzieli, że ojcowie wasi wszyscy przeszli przez Jordan i wszyscy zostali ochrzczeni w Jozuem w Duchu i w rzece"126.

Niektórzy autorzy dopełniają opowiadanie Joz 3,13-17 odnośnikami do Ps 113,3 , co wyraźnie czyni również Orygenes ${ }^{127}$. Zjawiska związane z odwróceniem biegu Jordanu odkreślane są jako „zatrzymanie się rzeki”. Lakonicznie opisywał to Hipolit Rzymski ${ }^{128}$ oraz późniejsi autorzy ${ }^{129}$. Rzymski prezbiter nie podzielał opinii o odwróceniu biegu Jordanu, lecz uważał, że rzeka kontemplowała tajemnicę Syna Bożego, który stał się człowiekiem ${ }^{130}$. Z kolei kaznodzieja z Rawenny z pierwszej połowy V wieku - Piotr Chryzolog wspominał, że rzeka zatrzymała swój bieg w obecności Arki Przymierza, ale nie cofnęła się w momencie Chrztu Chrystusa, by adorować objawienie się Trójcy Przenajświętszej ${ }^{131}$.

W kontekście chrzcielnym Orygenes nawiązał do wydarzenia, które miało miejsce zaraz po wyjściu z Jordanu: nakaz obrzezania kamiennymi nożami (por. Joz 5,2-9). Dla doktora aleksandryjskiego osoba Jozuego jako typ Chrystusa jest elementem jednoczącym biblijne fakty. Jak Jozue przechodził przez Jordan na czele Izraelitów i był pośrednikiem między ludem a Bogiem w momencie obrzezania, tak Chrystus stoi w centrum sakramentu chrztu, obiecując zbawienie i oczyszczenie z grzechów każdego chrześcijanina. Obrzezania dokonywano kamiennymi nożami, zaś oczyszczenia na chrzcie dokonuje Chrystus $^{132}$.

Drugie obrzezanie spełnia funkcję wód Jordanu, które obmywają przechodzącego przez rzekę, a więc zrzucają z niego hańbę egipską ${ }^{133}$, co jest synoni-

\footnotetext{
126 In Joannem VI,44.

127 Por. Homilia in Jos. IV,1.

128 Por. In Danielem II 19,5.

129 Por. Hilary Poitiers, In Psalmum 51,6 i Grzegorz z Nazjanzu, Carmen I,36.

130 Por. M. Marcovich (wyd.), Hippolytus. Refutatio omnium haeresium, s. 30-35.

131 Por. Sermo 45.

132 Orygenes posłużył się słowami św. Pawła: „Kamień, którym jest Chrystus” (1 Kor

133 Por. także In Joannem VI,45.
} $10,4)$. 
mem zła ${ }^{134}$. Innymi słowy „są oczyszczeni $\mathrm{z}$ osadu trądu ${ }^{135}$ i otrzymują podwójną łaskę"136. Wzmianka o „oczyszczeniu z trądu” nawiązuje do epizodu uzdrowienia Naamana, walecznego wodza syryjskiego. Literatura chrześcijańska postrzegała ten epizod jako zapowiedź sakramentu chrztu - „ozdrowieńczego obmycia”, które dokonuje się przez działanie Ducha i znak wody ${ }^{137}$.

W „drugim obrzezaniu”"138 zawsze działa Chrystus, lecz od człowieka wymaga się odpowiedniej postawy i właściwego nastawienia. Dlatego Orygenes przedstawia w swoich homiliach warunki przystąpienia do chrztu. Ukazuje, jaka powinna być postawa proszącego o ten sakrament: „Nikt więc, jeśli całkowicie się nawrócił, jeśli z serca żałował, jeśli w wierze przeszedł bieg Jordanu, jeśli został oczyszczony przez Ewangelię w drugim obrzezaniu, nie boi się hańby dawnych grzechów" ${ }^{139}$. Podobnie, jak Izraelici przechodzący Jordan pod wodzą Jozuego, czynili to z polecenia Bożego i z wiarą, tak samo chrześcijanin musi przystąpić do chrztu z takim nastawieniem. Wiara to warunek sakramentalnego oczyszczenia ${ }^{140}$. Adamancjusz porusza tę kwestię, gdy mówi o wnikaniu w Boże tajemnice czy o poznaniu prawdy ${ }^{141}$. Stawia w ten sposób kwestię osobistego pogłębienia zasad wiary przekazanej przy chrzcie. On sam deklarował, że wiara powinna wzrastać, stając się „poznaniem” i „wiedzą"142.

Chociaż nie podważano ważności wiary, jednak Aleksandryjczyk uznał za konieczną obronę wartości Ewangelii: „Jeżeli wszyscy ci, którzy zostali ochrzczeni, zachowali słodycz łaski niebieskiej, którą otrzymali, i jeśli żaden nie obrócił się ku goryczy grzechu, nie byłoby oczywiście napisane, że jedna część rzeki została rzucona w otchłań Morza Słonego"143. Człowiek ochrzczony porzuca więc grzech, a jego miejsce zajmuje nadprzyrodzona łaska, zamiast

134 Homilia in Jos. IV,2.

135 Na temat trądu identyfikowanego z grzechem zob. Orygenes, Homilia in Numeros VII.

136 In Joannem VI,48.

137 Ireneusz z Lyonu pisał, że chrześcijanin otrzymuje Ducha Świętego za pośrednictwem chrztu z wody; por. Adversus haereses III,17,2.

138 Wzmiankuje je Afrahat w Demonstratio XI,10.

139 Homiliae in Jos. V,6.

140 Klemens Aleksandryjski przemilczał podstawowe zasady wiary, lecz niewątpliwie zakłada ich znajomość przez czytelników. Por. Stromata VII,15,90, gdzie wspomiane jest wyznanie wiary podczas obrzędów chrzcielnych.

141 Por. Homiliae in Jos. IV, 1 V,1.

142 Jest to terminologia gnostycyzmu chrześcijańskiego. Por. L. Perrone, Fede/ragione, w: A. Monaci Castagno, Origene. Dizionario: la cultura, il pensiero, le opere, s. 156.

143 Homiliae in Jos. IV,2. Na temat Morza Martwego por. Pliniusz Starszy, Naturalis historia V 15. 
goryczy pojawia się słodycz. Tak więc dusza została uzdrowiona ${ }^{144}$. Natomiast ta część rzeki, która wpada do Morza Słonego symbolizuje ona grzech i to wszystko, co jest złe. Orygenes wyjaśnia to w następnym zdaniu: „Są pośród nich ci, którzy otrzymują święty chrzest i dają się zawładnąć światem, oddają się powabom pożądliwości. Ich symbolem [jest] ta część wód, która odpływa do morza i gubi się w słonej fali"145. Według doktora aleksandryjskiego wody spływające do morza symbolizują nie tylko zło, odrzucone w czasie chrztu, ale także tych chrześcijan, którzy na nowo powracają do praktyk grzesznych i niegodziwych $^{146}$.

Jordan stanowił bramę „nowej ziemi”. W homiliach o Joz Orygenes pisze: „Ale kiedy przybędziesz do duchowego źródła chrztu... po przejściu Jordanu, wejdziesz do ziemi obiecanej, do tej ziemi, gdzie Jezus [Jozue], po Mojżeszu, podtrzymuje ciebie i staje się przewodnikiem twojej nowej drogi"147. Podobną myśl Orygenes wyraża w innym zdaniu: „Spieszmy się więc przejść..., abyśmy zasłużyli na dojście do obiecanej szczęśliwości” ${ }^{148}$. Autor mówi także, że ci osiągną „obiecaną szczęśliwość” ${ }^{149}$, którzy usunęli całą pychę i grzech oraz przyjęli pokorę Chrystusa ${ }^{150}$. Każdy „pouczony przez [prawo Boże] i pokierowany [przez nie] przeprawi się przez Jordan, powinien dążyć aż do Ziemi Obiecanej, to znaczy przez łaskę chrztu dotrzeć do nauk ewangelicznych... Wyjście z Egiptu symbolizuje sytuację, gdy dusza porzuca ciemności tego świata oraz ślepotę cielesnej natury i przenosi się do innego wieku, który oznacza albo «łono Abrahama» (por. Łk 16,22) ${ }^{151}$, jak w przypadku Łazarza albo raj, jak w przypadku

144 O uzdrowieniu duchowym por. np. Contra Celsum I,64; VIII,51. Zbiór tekstów Orygenesa inspirowanych medycyną i ich klasyfikację przedstawia D.G. Bostock, Medical Theory and Theology in Origen, s. 191-199.

145 Homiliae in Jos. IV,2.

146 Na temat powrotu na drogę zła por. De principiis III,17; De oratione 29,13.

147 Homiliae in Jos. IV,1.

148 Ibidem.

149 Aleksandryjczyk podnosi obietnice szczęśliwości na poziom nadprzyrodzony (zob. Homilia in Jos. II,3. In Ps. 36,5). Należy podkreślić, że uduchowienie porównań i wyrażeń Psałterza staje się równie wyraźne u innych autorów pozostających pod wpływem Aleksandryjczyka. W ścisłym związku z jego twórczością pozostają komentarze do Pseudo-Hilarego, Ambrożego i Hieronima. Podobne zestawienie jest możliwe w przypadku Dydyma Ślepego i Euzebiusza z Cezarei.

150 Homiliae in Jos. V,1.

151 Wyrażenie często używane, chociaż przypowieść o bogaczu i Łazarzu nie jest szczególnie komentowana przez Orygenesa. Por. In Matthaeum XV,25. 
łotra (por. Łk 23,43) ${ }^{152}$, który uwierzył na krzyżu, albo inne, znane Bogu miejsca lub inne siedziby przez które przechodzi dusza wierząca w Boga i dotarłszy do owej «rzeki, która rozwesela miasto Boże» (por. Ps 46 [45],5), otrzymuje nad nią dziedzictwo przyobiecane przodkom"153. W komentarzu do Czwartej Ewangelii Orygenes w znamienny sposób podsumowuje swoje rozważania: „W sposób godny pojmując rzekę Jordan, chrzest w niej, dom przygotowania, oraz fakt, że Jezus tu właśnie został ochrzczony, w miarę możliwości korzystajmy z tak ogromnej mocy, jaką daje ta rzeka"154.

W rozważaniach Adamancjusza postać Jozuego jest tak ściśle utożsamiona $z$ Jezusem, że często trudno rozstrzygnąć, o kim jest mowa. Autor jednym tchem wylicza chrzest i przejście przez Jordan. „Wydaje się jednak, że mowa jest o Jozuem jako opozycji (w typologii) do Mojżesza i jako zapowiedzi Jezusa Chrystusa. Każdy ochrzczony staje się dziedzicem ziemi obiecanej i do niej wchodzi. Jest to bezpośredni skutek oczyszczenia i usprawiedliwienia dokonanego w chrzcie świętym" ${ }^{55}$. Chrzest Mojżesza „w obłoku i w morzu” jest niedoskonały. „Miał [on] w sobie coś surowego i przykrego, ponieważ [Izraelici] bali się jeszcze wrogów i krzyczeli do Pana. Ale chrzest według porządku Jozuego [Jezusowego] w rzece, naprawdę słodki i możliwy do wypicia, jest doskonalszy niż [chrzest Mojżeszowy]"156. Słodycz łaski jest więc wynikiem innego porządku chrztu Jezusa. Jego łaska sprawia, że chrześcijanin obdarzony został pokojem. Chrzest Jezusowy jest doskonalszy od Mojżeszowego, bo jest „słodki” dla przyjmującego, jest dopasowany do jego natury, odpowiada jego zapotrzebowaniu. Wszystko „dokonało przez wzgląd na naród Starego Przymierza”157. Wydarzenia zbawcze Starego Testamentu zostały w chwili chrztu uwznioślone, bo ich skutek jest nie tylko doczesny, ale także wieczny. Już na początku swego cyklu homiletycznego egzegeta aleksandryjski wskazuje, że przejście przez rzekę Jordan, aby wziąć w posiadanie Ziemię Obiecaną, było cieniem i zapowiedzią tego uroczystego wejścia do życia wiecznego, jakie pod wodzą Pana Jezusa rozpoczyna się przez przyjęcie chrztu ${ }^{158}$ : „Pod wodzą Pana mojego, Jezusa,

152 Orygenes przywołuje ten fragment w: Homiliae in Genesim XV,5; Homiliae in Leviticum IX,5; Homiliae in Ezechielem XIII,2; De principiis II,11; In Joannem XXXII; In Romanos III,9; V,9.

153 Homilia in Numeros XXVI,4.

154 In Joannem VI, 48.

155 M. Spyra, Elementy teologii chrzcielnej w czwartej i piątej homilii Orygenesa, s. 56.

156 In Joannem VI,43-44.

157 Homiliae in Jos. IV,1.

158 Por. J. Salij, Ksiega Jozuego jako proroctwo, s. 119. 
przychodzę nad Jordan, a przychodzę nie w zamieszaniu ${ }^{159}$, spowodowanym ucieczką ani nieprzerażony strachem, lecz przybywam wraz z kapłanami niosącymi Arkę Przymierza Pańskiego, w której przechowywane jest Prawo i boskie zapisy. Wkraczam w Jordan nie w ukradkowym milczeniu, lecz pośród pieśni trąb, które grają mistyczną i boską pieśń, abym mógł przystąpić do przepowiadania trąby niebieskiej"160.

W opinii Orygenesa każdy ochrzczony wchodzi w szczególną relację z tym, który dokonuje oczyszczenia, umacnia, wprowadza na nową drogę. Chrzest daje możliwość przebywania na zawsze z Chrystusem. On też jest przewodnikiem w nowej ziemi, co Aleksandryjczyk ukazuje w szerzej perspektywie. W swoich homiliach wyjaśnia: „W czasie przejścia przez Jordan Jozue słyszy: «Dziś pocznę cię wywyższać w oczach całego Izraela» (Joz 3,7). Przed tajemnicą chrztu Jezus nie jest wywyższony, ale począwszy od tego momentu, zaczyna być wywyższony, i to wywyższony w oczach swojego ludu. Jeżeli bowiem «wszyscy ci, którzy otrzymali chrzest zanurzający w Chrystusa Jezusa, zostali zanurzeni w Jego śmierci» (Rz 6,3), zaś śmierć Chrystusa zrealizowała się dopiero przez wywyższenie krzyża, zgodzić się można, że Jezus jest wywyższony przez każdego wiernego dopiero w momencie tajemnicy chrztu; jest napisane: «Bóg Go wywyższył i dał Mu imię, które jest ponad wszelkie imię» (Flp 2,9-10)"161. Jozue zapowiada szczególne wywyższenie Jezusa. Odbywa się to wobec całego ludu izraelskiego. Czyni to Bóg zgodnie z tym, co napisał św. Paweł w Flp. Orygenes nie uzasadnia dokładniej wywyższenia przez chrzest, jednak w kontekście całej homilii widać, że przed obmyciem winy człowiek nie jest przygotowany na to Objawienie i spotkanie z Chrystusem. Aleksandryjczyk mówi o dwóch podmiotach wywyższających Jezusa. Jest to przede wszystkim Bóg. Jak się dokonuje to Objawienie, określa Autor w innym miejscu: „Trzeba, aby Bóg wywyższył Go także wobec nas. A jest wywyższony względem mnie wtedy, gdy zostają mi ukazane: wielkość i wzniosłość Jego Boskości. Kiedy więc

159 Od czasów Dydyma Ślepego „zamieszanie” łączono z wizerunkiem Babilonii; por. In Zachariam I,132.

160 Homiliae in Jos. I,3. W brzmieniu trąb Orygenes dopatruje się zapowiedzi Sądu Ostatecznego. W Nowym Testamencie trąbienie symbolizuje sąd Boży, a Zbawiciel zapowiada, że Syn Człowieczy „pośle swoich aniołów z trąbą o głosie potężnym i zgromadzą Jego wybranych” (Mt 24,31). Św. Paweł pisze w 1 Kor: „W jednym momencie, w mgnieniu oka, na dźwięk ostatniej trąby - zabrzmi bowiem trąba -umarli powstaną" (1 Kor 15,52). Natomiast w 1 Tes tenże apostoł stwierdza: „Sam bowiem Pan zstąpi z nieba na hasło i na głos archanioła, i na dźwięk trąby Bożej, a zmarli w Chrystusie powstaną pierwsi” (1 Tes $4,16)$.

161 Homiliae in Jos. IV,2. 
miałem to Objawienie? Dokładnie w momencie przejścia Jordanu"162. Aleksandryjski autor pisze więc, na czym polega Objawienie w momencie chrztu. Jak Izraelita doświadczył szczególnej obecności Boga w chwili przejścia przez Jordan, tak każdy przyjmujący chrzest odczuwa obecność Zbawiciela i widzi Jego wielkość oraz wzniosłość Jego Boskości. Jest to rezultat oświecenia człowieka ${ }^{163}$, poznającego prawdy niewidzialne. To właśnie na tym fundamencie wznosi się gmach wyższego stopnia poznania. Adamancjusz jest przekonany, że Zbawca przekazał swoim uczniom ukryte tajemnice. „Chrystus nakazuje im [apostołom], aby każdemu kto stanie się światłością, głosili tajemnice, które zostały im przekazane, $\mathrm{z}$ dala od uszu tłumu i niejasno, a mają to robić wówczas, gdy będą oświeceni" ${ }^{164}$.

Szczególnie interesująca wydaje się rekonstrukcja faktów dokonana przez Euzebiusza z Cezarei. Metropolita Palestyny scalił Joz i Ps 113,3. „Wszyscy synowie Izraela przeszli przez koryto rzeki pośrodku Jordanu, podczas gdy [nurt] dolnego biegu płynął ku Morzu Słonemu ${ }^{165}$, a [bieg] dolny, zatrzymując się w cudowny sposób, cofnął się [na rozkaz] mocy Bożej. I rzeczywiście, nurt biegnący z góry od źródeł, nie mając ujścia, podnosił się [wysoko] i nagromadziła się masa wód płynących, gdy nie było dla nich odpływu" ${ }^{166}$. Znający realia palestyńskie komentator, opisuje przejście Jordanu jako niewątpliwy cud, spowodowany potęgą „mocy Bożej”.

Dla Afrahata wydarzenia opisane w księdze Joz znamionowały wiarę jej centralnej postaci. Nie ulega wątpliwości, że „Jozue, syn Nuna rozdzielił Jordan dzięki swej wierze, a synowie Izraela, jak w czasach Mojżesza, przeszli przez [rzekę]. Jednak trzeba wiedzieć, moi umiłowani, że droga przez Jordan była trzykrotnie otwierana poprzez rozdzielenie się [wód]. Pierwszy raz przez Jozuego, Syna Nuna, drugi raz przez Eliasza i wreszcie przez Elizeusza $(2 \mathrm{Krl}$ 2,8-15... Ponadto, gdy lud przeszedł [Jordan] za dni Jozuego, syna Nuna, [było to]..., jak napisano, naprzeciw Jerycha (por. Joz 3,17). Także przez wiarę, Jozue, syn Nuna sprawił, że Izraelici posiedli kraj"167.

162 Ibidem, V,3.

163 To apostołowie przekazali wspólne i niezbędne zasady, które poznają ochrzczeni czyli „oświeceni”. Wg Orygenesa użyte przez Zbawcę wyrażenie w J 4,21 b „oznacza powszechną regułę Kościoła, ponad którą wzniesie się człowiek doskonały i święty, który w sposób bardziej kontemplacyjny, wyraźny i zbożny czci Ojca”. In Joannem XIII,16,98.

164 In Joannem II,28,174.

165 Jedno z określeń Morza Martwego. Inne znane w starożytności nawiązywało do wydobywanego tam asfaltu (Morze Asfaltowe).

166 In Psalmum 41.

167 Afrahat, Demonstratio I, 16. 
Efrem Syryjczyk nawiązuje do kontekstu paschalnego Joz $5^{168}$. „W miesiącu kwiatów, rzeka Jordan rozdzieliła swoje nurty przed znakiem swojego Pana. W czasie [zakwitania] kwiatów, brzmiały głosy radości i runęły mury przed Jozuem"169. Wzmianka o kwiatach to dosyć typowy zabieg literacki, który spotyka się w pismach patrystycznych odnoszących się przede wszystkim do Wielkanocy ${ }^{170}$. Kwiaty symbolizowały nadzieję zmartwychwstania, wiecznej wiosny i niebiańskiej radości w raju ${ }^{171}$.

Przekonanie o wyjątkowości wydarzenia opisanego w Joz 3,4-17 przyświecało także innym autorom, wśród których na szczególną uwagę zasługuje Paulin z Noli. „[To] Jozue, / na którego polecenie Jordan zatrzymał swe wody, / nurty stanęły przed Arką Bożą. / Niezwykła moc rozdzieliła rzekę: jedna część nurtu / zawróciła, i część [wód] rzeki popłynęła pospiesznie ku morzu i pozostawiła suche dno. Tam gdzie rzeka od źródła / płynęła wzburzona, wody wzniosły się wysoko, / jakby groźna góra z fal wyrosła, / połyskując falami jakby patrzyła z wysokości / na stopy stawiające kroki na wyschniętym dnie [rzeki] / i ślady ludzkie w pyle, zakrzepłe wyschniętym błocie"172.

Kompozycja biskupa Noli wprost roi się od aluzji i zapożyczeń z literatury klasycznej, przede wszystkim o charakterze epickim ${ }^{173}$. Nie chodzi jednak wyłącznie o upodobania literackie erudycję autora. Dla Paulina było ważne podkreślenie faktu, że Bóg chrześcijan ukazuje cudowną moc wobec natury, zmieniając jej odwieczne prawa. Epicki koloryt ma opis wypiętrzonych wód na kształt budzącej grozę góry stojącej przed Izraelem. Tego typu skojarzenia być może są związane $\mathrm{z}$ modelami ikonograficznymi ${ }^{174}$. Hipotyzuje się istnienie w bazylice św. Feliksa męczennika malowidła ściennego przedstawiającego przejście Izraelitów przez Jordan ${ }^{175}$.

\footnotetext{
168 Pascha dla Żydów była także wspomnieniem wejścia do Ziemi Obiecanej.
}

169 Hymni de azyma VIII,16-17. Efrem przedstawia podobną kolej wydarzeń, co Afrahat, który jednak dodał wzmiankę o przejściu Elizeusza przez Jordan po zabraniu do nieba Eliasza; por. Demonstratio I, 15-16.

170 Por. np. Efrem Syryjczyk, Hymni de risurrectione 2; Zenon z Werony, Tractatus II,45.

171 Zob. np. Jan Chryzostom, De resurrectione D.N. Jesu Christi 5.

172 Carmen XXVII, 518-528.

173 Szczegółowe wyliczenie źródeł w: G. Galeani, Iordanem novimus. La parafrasi prudenziana di Ios. 3,13-17 e Ps. 113,3 in perist. 7,66-70, s. 174, przypis 15.

174 Scena przejścia Izraelitow przez Jordan znajduje się na mozaikach ściennych w bazyli Matki Bożej Większej w Rzymie. Zob. S. Adamiak, Sześcioksiąg w mozaikach bazyliki Santa Maria Maggiore w Rzymie, s. 170.

175 Por. G.H. de la Portbarré-Viard, Descriptions monumentales et discours sur lédification chez Paulin de Nole. Le regard et la lumière (epist. 32 et carm. 27 et 28), s. 325. 
Przypisywany św. Ambrożemu hymn Illuminans Altissimus nawiązuje do Joz 3, ale wspomina także exempla Eliasza (2 Krn 2,8) i Elizeusza (2 Krn 2,14). W przeciwieństwie do innych autorów późnoantycznych, szczególnie poetów, biskup Mediolanu nie starał się opracować w formie lirycznej perykop biblijnych. Są jednak obecne wątki teologiczne, wskazujące na to, że Jordan nie tyle „odwrócił swój bieg”, co „połączył się ze źródłem” ${ }^{176}$. Nie jest to zmiana wyłącznie stylistyczna, ale szczegół ten należy traktować jako figurę powrotu człowieka przez chrzest do pierwotnej czystości i prostoty ${ }^{177}$. Wcześniej Dydym Ślepy deklarował, że „Jordan to nieśmiertelny chrzest” ${ }^{178}$. W tym duchu również biskup Mediolanu deklaruje: „Tam, gdzie jest Chrystus, tam znajduje się i Jordan"179, czyli źródło łaski. Ambroży utożsamia Jordan nie ze chrztem, ale z osobą Chrystusa, jak czynił to wcześniej Orygenes ${ }^{180}$. Basen chrzcielny nazywano nawet Jordanem ${ }^{181}$, a przez rozszerzenie pojęcia każda woda chrzcielna była określana w ten właśnie sposób. W Chronicon Paschale zredagowanym w VII wieku w Aleksandrii widać znaczenie dawane cytatowi Ps 113 (114),3 $3^{182}$.

Należąca do corpus pseudochrisostomicum homilia In Jordanem fluvium zawiera parafrazę Joz 4 i lekturę typologiczną tego fragmentu. Można dostrzec, że anonimowy kaznodzieja gromadzi różne elementy tradycji interpretacyjnej tego fragmentu biblijnego. „Ponieważ Jordan wysechł, jego koryto nie zniknęło, ale powróciło do swych dawnych początków, Jozue (t.j. Jezus), jak powiedziano, wziął dwanaście kamieni z Jordanu i postawił na brzegu, a dwanaście innych kamieni położył w Jordanie ${ }^{183}$. Co oznacza, że dwanaście kamieni wyjął i dwanaście innych położył na ich miejsce? To dlatego, że [Zbawca] zwyciężył śmiertelną naturę..., a nawet więcej ukazał, że podźwignął upadłą ludzkość i wyniósł do niebios. Kamienie, które nigdy nie widziały promieni słonecznych ani blasku, wyniósł na światło, a z głębokości wzięte, wyniesione zostały ponad ziemię. Dlaczego wziął dwanaście kamieni? Ponieważ poprzez dwunastu Apostołów podźwignął upadłą ${ }^{184}$ ludzką naturę... [Jozue] wyjął kamienie, by

176 Por. Hymnus VIII, 5-8. Podobne porównanie w In Lucam I 37 i Exaemeron III 1,6.

177 Por. A.V. Nazzaro, Simbologia e poesia dell'acqua e del mare in Ambrogio di Milano,

s. 75 .

178 De Trinitate II,14.

179 Sermo 38,2.

180 Zob. przede wszystkim In Joannem VI,42.

181 Czynią tak Sewer z Antiochii (V-VI w.) i Sofroniusz z Jerozolimy (VI-VII w.). Por. K. McDonnell, Jesus' Baptism in the Jordan, s. 225, przyp. 142.

182 Por. PG 92, kol. 545-547.

183 Autor parafrazuje Joz 4,5. 6 (wg LXX).

184 Dosł. „śmiertelną, jako paralelizm do wcześniejszego zdania. 
ukazać w słońcu i w świetle oraz ludowi, który nadejdzie później, w jaki sposób przeszli przez Jordan. Dlatego ukazuje powód: «Jeżeli, jak powiedziano, kiedyś potomkowie zapytają was: Co oznaczają te kamienie?» Pouczycie ich: «Przeszliśmy przez Jordan jak po suchej ziemi, Bóg, wysuszył przed nami wody Jordanu» ${ }^{185}$. Dlaczego z powrotem je tam położono? Wyciągnięto z głębokości, tych którzy w niej przebywali, uratowanym dano zbawienie. Położone kamienie dają pewność"186. Oszczędność symbolu kamieni stanowiła o jego wymowie i ogromnym znaczeniu. Zadziwiały one swoim niewzruszonym trwaniem, stąd stały się jednym z najsilniejszych znaków Bożej obecności.

O dwunastu kamieniach jako symbolu kolegium apostolskiego wspomina Grzegorz z Nyssy: „Hebrajczycy nie otrzymali Ziemi Obiecanej, zanim prowadzeni przez Jozuego, nie przeszli Jordanu. Jozue, wyciągając z nurtów [tej rzeki] dwanaście kamieni, zapowiedział w wyraźny sposób dwunastu apostołów, szafarzy chrztu” 187 . Nysseńczyk przypomina ponadto, że "Jozue, syn Nuna, wziął z Jordanu liczbę kamieni równą liczbie pokoleń Izraela, z nich zaś żaden nie okazał się bezwartościowy, bo wszystkie zostały zebrane z takim samym szacunkiem, na świadectwo tajemnicy, jaka dokonała się w Jordanie"188.

Hilary z Poitiers ubogaca typologię Jozue - Jezus o elementy nawiązujące do Synagogi i Kościoła. „Jak pierwszy [Jozue] rozdzielił wody, tak drugi podzielił ludy"189, pisze. Następnie kontynuuje swój wywód: „Jak pierwszy rozstawił na ziemi dwanaście kamieni wyciągniętych z głębiny na wiecznotrwałe świadectwo, a z ziemi wzięte umieścił na głębinie, tak drugi nauką apostolską i wywiódł z Synagogi i w Synagodze zostawił, aby ona mogła z niej korzystać nawet teraz, jeśli tylko zechce; ponieważ nauka apostolska, którą zapowiadało dwanaście kamieni, na wiecznotrwałe świadectwo, została przejęta z Prawa, mimo, że pozostaje w Prawie"190.

Prudencjusz, podobnie jak inni Ojcowie Kościoła ${ }^{191}$, starał się ująć w poetyckie wersety powody, dla których Pan wybrał właśnie dwunastu apostołów:

185 Parafraza Joz 4,21.22.23 (wg LXX).

186 In Jordanem fluvium 5. Ta część homilii nawiązuje do następnej sekcji (osią pojęciową są czasowniki „zabierać” i „dawać”).

187 De baptismo Christi.

188 In Canticum VI (194). Odnośnik do Joz 4,4-9.

189 Autor nawiązuje do Mt 10,34; Łk 12,51 i Joz 4,1.

190 De mysteriis II,2,6.

191 Tertulian wyjaśniał dlaczego Zbawiciel wybrał dwunastu apostołów, a nie jakąś inną liczbę przywołując Wj 28,9-12; Lb 33,9 oraz Joz 4 czyli „dwanaście kamieni wydobytych przez Jozuego z Jordanu i złożonych w Arce Przymierza. Tyluż właśnie miało być apostołów; tak jak źródła i rzeki mają oni znowu nawodnić suchą, pozbawioną znajomości Boga ziemię ludów - jak to powiada Izajasz: «Dostarczę rzek na pustkowiu» (Iz 43,20)... Jak ka- 
„Prawdziwy już / Jozue, co w późniejszy czas / jako zwycięzca ludziom swym / ziem obiecanych daje łan. / On też dwanaście w końcu wbił / kamieni w wód rozdartych dno / i mocno je osadził tam / Dwunastu apostołów chór" ${ }^{\prime 192}$.

Św. Augustyn z Hippony uznał za stosowne, aby słuchaczom wyjaśnić metaforę Jordanu odwołując się do specyficznego kontekstu Joz 3,14-17. „Rzeka Jordan, gdy [Izraelici] przekraczali ją wchodząc do Ziemi Obiecanej, gdy dotknęły jej stopy kapłanów niosących Arkę [Przymierza], strumień wód zatrzymał się w górnym biegu, a w dolnej części popłynął do morza, aż cały lud przeszedł (por. Joz 3, 15-17)... Wiemy to wszyscy, ale tego nie powinniśmy sobie wyobrażać w tym Psalmie, na który odpowiedzieliśmy śpiewając «Alleluja», bowiem zamiarem Ducha Świętego jest [to byśmy], gdy przywołujemy na pamięć czyny z przeszłości, nie uważali ich za takie, które już nastąpiły. Wszystko to, jak powiedział Apostoł, przydarzyło się celem pouczenia (por. 1 Kor 10,11)"193.

Skrótowość opisu Ps 114 (113), zdaniem Hippończyka, została spowodowana wolą Psalmisty by nie opisywać faktów, które się dokonały, lecz ukazać przyszłość i Boże plany. Wydarzenia związane z przejściem Jordanu miały znaczenie symboliczne i profetyczne, stąd także różnica w opisach biblijnych ${ }^{194}$.

Opis rozdzielania wód Jordanu podaje pseudochryzostomowe kazanie In Jordanem fluvium. Autor przypomina, że „trzykrotnie Bóg rozdzielił Jordan, tak iż jego nurt nie kończył się w Morzu Martwym, lecz powrócił do ożywczych źródeł. Był on rozdzielony przez Jozuego, syna Nuna..., Eliasza... i Elizeusza. Jako pierwszy [uczynił to] Jozue, syn Nuna... W jaki sposób? On nie odwrócił nurtu źródeł, lecz skierował wody wstecz, jak poświadcza Psalmista: Cóż ci jest, morze, że uciekasz? Czemu, Jordanie, bieg swój odwracasz? (Ps 114 [113A],5). Odwracaniem są źródła. W rezultacie nasz Zbawiciel przemienił naszą naturę, zdążającą ku śmierci..., by powróciła do dawnych źródeł życia. Nasza śmiertelna natura powróciła do swej pierwotnej formy"195. Odrodzenie człowieka po powrót do jego stanu sprzed grzechu pierworodnego. Osią konstrukcji myślowej kaznodziei jest pojęcie odwracania: Jak Jozue odwrócił bieg Jordanu, tak Chrystus odwraca losy ludzkości.

mienie, niewzruszone dzięki wierze, które z wód Jordanu wydobył prawdziwy Jezus i przyjął do świętego skarbca swojego przymierza”; Adversus Marcionem IV, 13. Zob. również Piotr Chryzolog, Sermo 170.

192 Cathemerinon XII, 168-180.

193 In Psalmum 113,1.

194 Por. G. Galeani, Iordanem novimus, s. 173.

195 In Jordanem fluvium 3. 
Pojawiająca się w opisie Joz Arka Przymierza ${ }^{196}$ to typ nowotestamentowych tajemnic i jednocześnie symbol wcielonego Syna Bożego ${ }^{197}$. Bóg dał ją Izraelitom jako symbol swego przymierza, a zarazem odpowiadający ludzkim potrzebom konkretny znak swojej obecności i pomocy. Zwraca na to uwage Hilary z Poitiers, gdy komentuje Joz 3,1. „Przez to oznaczenie dano do zrozumienia, że gdy nadejdzie Arka Boga, to jest gdy przyjdzie Bóg w ciele, część ludzi zawróci z drogi grzechu i własnej śmierci, druga natomiast część spłynie do morza, to znaczy podzieli los potępionego świata"198. Tak więc, jak przekonuje pewien anonimowy kaznodzieja grecki, „żadne z rozdzieleń [wód] Jordanu nie odbywa się bez symbolu. Jozue, syn Nuna [uczynił to] za pomocą Arki. Śmiertelna natura sama z siebie nie była dostatecznie silna, by powstrzymać nurt Jezus (Jozue) tam wszedł, przyjmując miano mistrza, i niosąc Arkę, symbol ciała Mistrza. Jordan wyraźnie nie jest posłuszny Jozuemu, tylko zwykłemu człowiekowi - mówię tutaj o synu Nuna - nie oddaje czci Żydom, ani nie szanuje kapłanów. To jest ukazane przez to, że nie ustępuje przed ludem, lecz zatrzymuje się przed Arką, jak rzekł Jozue: «Oto Arka Pana całej ziemi przechodzi przez Jordan. Skoro tylko stopy kapłanów niosących Arkę Pana, Boga całej ziemi, staną w wodzie Jordanu, oddzielą się [jego] wody» (por. Jóź 3,11.13), nie przez szacunek do kapłanów, ale Arki”'199. Kaznodzieja łączy Ps 114 (113 A),5 oraz 7 i konkluduje: „Obliczem Pana ${ }^{200}$ był kształt Arki”201.

Różnorodne aspekty symboliki zawartej w scenie przejścia Izraelitów przez Jordan są nawiązaniem do rzeczywistości chrześcijańskiej. Gdy Jan, poprzednik Pana, chrzcił w Jordanie, jego działalność była bezpośrednim przygotowaniem na niezwykłe wydarzenie, które miało nastąpić: publiczne wystąpienie „umiłowanego Syna” Bożego, drugiego Jozuego i wodza nowego ludu wybranego.

„W ten sposób [lud] przekroczył Jordan i Jordan stał się początkiem zdobywania kraju przez Jozuego syna Nuna. Od czasu, gdy przybył nad Jordan, nie odziedziczył on Ziemi Obiecanej. Do czasu, zanim Chrystus nie przybył nad Jordan, nie było głoszone Królestwo. Początkiem posiadanie ziemi [Izraela]

196 Arka Przymierza zajmuje pierwsze miejsce wśród przedmiotów kultu, które Bóg nakazał sporządzić (por. Wj 25-28) jako „obrazy rzeczy niebieskich” (Hbr 9,23).

197 Symbol ten odnosi się również do Matki Bożej. Por. Modest z Jerozolimy, Encomium in Beatam Virginem 4.

198 De mysteriis II,2,7.

199 In Jordanem fluvium 4.

200 Gr. prosopon. W następnym paragrafie autor cytuje w odniesieniu do Arki 1 Krl 8,9 (LXX) i Hbr 9,4. Wg Wniebowstapienia Izajasza Syn Boży spełniał rolę przewodnika, prowadząc wybranych przed oblicze Boga; zob. Ascensio Isaiae 9,39.

201 In Jordanem fluvium 4. Następnie cytowany jest Ps 132 (131),8: „Wyrusz, o Panie, na miejsce Twego odpocznienia, Ty i Twoja arka pełna chwały”; ibidem 5. 
jest Jordan, początkiem posiadanie królestwa niebieskiego [także jest] Jordan. $\mathrm{Z}$ tego powodu prorok powiedział: «Wspominam Cię, Panie, z ziemi Jordanu» (Ps 41 [42],7 [LXX]). Wspomnienie [to] nie ustanie"202.

Egzegeci i kaznodzieje chrześcijańscy komentując Joz 3-4 przypominali znaczenie opisanych tam wydarzeń. Z jednej strony było to dla nich odnowienia cudów dokonanych przez Boga nad Morzem Czerwonym (por. Wj 14,531). Arka Przymierza, niesiona przez kapłanów, powstrzymuje wody Jordanu, aby lud mógł przejść suchą nogą do ziemi obietnicy (Joz 3). Dwanaście kamieni, wydobytych z łożyska rzeki, ułożono w Gilgal jako znak upamiętniający to niezwykłe wydarzenie (Joz 4). Jednak z drugiej strony ma się do czynienia z typologią o głębokim znaczeniu chrystologicznym i soteriologicznym. Odczytywano Joz jako prefigurację dzieła zbawczego Chrystusa, stąd połączenie ze sceną chrztu Pańskiego. Podobnie jako Jozue zastąpił prawodawcę Mojżesza, tak i w porządku łaski w osobie Odkupiciela zostaje zastąpiony porządek dawnego Prawa. Autorzy wczesnochrześcijańscy widzieli także inne wymiary narracji Joz 3-4: eklezjalny i sakramentalny oraz moralno-duchowy.

\section{Bibliografia}

Abbaye Sainte-Marie de la Pierre-qui-Vire, Lexpérience de Dieu dans la vie monastique, Saint-Léger-Vauban 1973.

Abgarowicz K. (tłum.), J. Sajdak, J. Wikariak, Św. Ambroży z Mediolanu. Obowiazzki duchownych, Warszawa 1967.

Adamiak S., Sześcioksiag w mozaikach bazyliki Santa Maria Maggiore w Rzymie, Biblica et Patristica Thoruniensia 4 (2011), s. 165-179.

Augustyniak K. (tłum.), Stanula E. (wstęp i oprac.), Orygenes. Komentarz do Ewangelii według Mateusza (ŹMT 10), Kraków 2003 (wznowienie).

Bagatti B., Excavations in Nazareth, t. 1: From the Beginning till the XII Century (Collectio maior SBF 17), tłum. ang. E. Hoade, Jerusalem 1969.

Baldi D. (wyd.), Enchiridion Locorum Sanctorum. Documenta S. Evangelii Loca Respicientia, Jerusalem $1982^{3}$.

Banterle G. (wyd.), Ambrogio di Milano. Discorsi e Lettere I; II/1; II/II; II/III, tom 1-4 (Opera Omnia di Sant'Ambrogio 18-21), Milano-Roma 1985; 1988.

Banterle G., Olivar A. (wyd.), Pietro Crisologo. Sermoni 1-62 bis, w: Opere di San Pietro Crisologo, t. 1, Roma 1996.

Bardski K., Chrystologiczna interpretacja Księgi Jozuego u Orygenesa, Collectanea Theologica 84 (2015) z. 4, s. 197-202.

202 In Jordanem fluvium 6. 
Bardy G., Lefevre M. (wyd. i tłum.), Hippolyte de Rome. Commentaire sur Daniel (SC 14), Paris 1947.

Barnes T.D., The composition of Eusebius' Onomasticon, Journal of Theological Studies 26 (1975) s. 412-415.

Bauer J.B., Schrenk S., Jordan, w: Reallexicon für Antike und Christentum, t. 18, Stuttgart 1998, s. 699-715.

Beck E. (wyd.), Des Heiligen Ephraem des Syrers Paschahymnen (De azymis, De crucifixione, De resurrectione) (CSCO: Scriptores Syri 248), Lowanium 1964.

Bielawski M., Blask ikon, Kraków 2005.

Borkowska M. (tłum.), Makowiecka E. (wstęp,), Wipszycka E., Starowieyski M. (oprac. i red.), Apoftegmaty Ojców Pustyni, t. 1, Gerontikon. Księga Starców (ŹM. Starożytność 4), Kraków-Tyniec 2004.

Bostock D.G., Medical Theory and Theology in Origen, w: Origeniana Tertia, Roma 1985, s. 191-199.

Brisson J.-P. (texte établi et trad. avec. introd. et notes par), Hilaire de Poitiers. Traité des mysteres (SC 19), Paris 1978.

Brożek M. (tłum., wstęp i oprac.), Aureliusz Prudencjusz Klemens. Poezje (PSP 43), Warszawa 1987.

Dąbrowska E. (tłum., wstęp, koment.), Kosiński R. (indeksy), Cyryl ze Scytopolis. Żywoty mnichów palestyńskich (ŹM. Starożytność 36), Kraków-Tyniec 2011.

Daniélou J., Bible et liturgie. La théologie biblique des sacrements et des fêtes d'après les Pères de l'Église (Lex orandi 11), Paris 1958.

Daniélou J., L'entrée dans l'histoire du Salut. Bapteme et confirmation, Paris 1967.

Daniélou J., Qu'est ce que la typologie? L'Ancien Testament et les chrètiens, Paris 1941.

Daniélou J., Sacramentum Futuri. Etudes sur les origines de la typologie biblique, Paris 1950.

Daniélou J., Traversée de la Mer Rouge et Baptême aux premières siécles, Recherches de sciences religieuse 33 (1946) s. 402-430;

Doelger F.J., Der Durchzug durch den Jordan als Sinnbild der christlichen Taufe, Antike und Christentum 2 (1930), s. 70-79.

Doignon J. (wyd.), Sancti Hilarii Pictaviensis episcopi opera: Tractatus super Psalmos, Instructio Psalmorum in Psalmos I-XCI, pars I,1 (CCL 61), Turnhout 1997.

Doutreleau L. (wyd. i opr.), Didyme l'Aveugle. Sur Zacharie. Texte inédit d'après un papyrus de Toura, t. 1-3 (SC 83; 84; 85), Paris 1962.

Dus J., Die Analyse zweier Ladeerzählungen des Josuabuches (Jos 3-4 and 6), Zeitschrift für die alttestamentliche Wissenschaft 72 (1960), s. 107-134.

Franceschini E., Weber R. (wyd.), Itineraria et alia geographica (CCL 175), Turnhout 1965.

Fritz V., Das Buch Josua (Hadbuch zum Alten Testament 1/7), Tübingen 1994.

Galeani G., Iordanem novimus. La parafrasi prudenziana di Ios. 3,13-17 e Ps. 113,3 In perist. 7,66-70, Il calamo della memoria 6 (2014), s. 171-187.

Geyer P. (wyd.), Itinera Hierosolymitana saeculi III-VIII (CSEL 39), Vindobonae 1898.

Grant McQueen R. (wyd.), Irenaeus of Lyons. Against Heresies (The Early Church Fathers), London 1997. 
Grego I., San Gregorio di Nissa pellegrino in Terra Santa, Salesianum 38 (1976) s. 109-125 .

Hausherr I., Direction spirituelle en Orient autrefois (Orientalia Christiana Analecta 144), Roma 1955.

Hawk L.D., Every Promise Fulfilled: Contesting Plots in Joshua, Louisville-Westminster 1991.

Hubbard R. L., „What Do These Stones Mean”? Biblical Theology and a Motif in Joshua, Bulletin for Biblical Research 11 (2001), nr 1, s. 1-26.

Jaubert A. (wyd. i tłum.), Origène. Homélies sur Josué (SC 71), Paris 1960.

Kalinkowski S. (tłum. i oprac.), Stanula W. (wstęp), Orygenes. Homilie o Księgach Rodzaju, Wyjścia Kapłańskiej (PSP 23), z. 1-2, Warszawa 1984.

Kalinkowski S. (tłum. i oprac.), Stanula W. (wstęp), Orygenes. Homilie o Księgach Liczb, Jozuego i Sędziów (PSP 34), z. 1-2, Warszawa 1986.

Kalinkowski S. (tłum.), Stanula W., Myszor W. (oprac.), Orygenes. Komentarz do Ewangelii św. Jana (PSP 28), Warszawa 1981.

Kania W. (tłum.), Starowieyski M. (wstęp i opr.), Św. Jan Chryzostom. Katechezy chrzcielne (Homilie katechetyczne do tych, którzy mają być oświeceni oraz do neofitów), t. 1-2 (U źródeł katechumenatu 1-2), Lublin 1993-1994.

Kania W. (tłum.), Św. Cyryl Jerozolimski. Katechezy przedchrzcielne i mistagogiczne (BOK 14), Kraków 2000.

Kaswalder P., La terra della promessa. Elementi di geografia biblica (SBF Collectio Minor 44), Jerusalem 2010.

Kaswalder P.A., Onomastica biblica. Fonti scritte e ricerca archeologica (Collectio Minor 40), Jerusalem 2002.

Khouri R., Where John Baptized: Bethany Beyond the Jordan, Biblical Archaeology Review, 31 (2005), s. 34-43.

Klosterman E. (wyd.), Eusebius. Das Onomastikon der biblischen Ortsnamen (GCS 11/1), Leipzig 1904 [nowe wyd. Hildesheim 1966].

Kozera M. (tłum.), Marek Starowieyski M. (wstęp), Pollok J. (bibliogr.), Apoftegmaty Ojców Pustyni, t. 2, Kolekcja systematyczna (ŹM. Starożytność 9), Kraków-Tyniec 2007

Kroymann A., Dekkers E., Borleffs J.G.Ph., Waszink J.H. (wyd.), Quinti Septimi Florentis Tertulliani opera, pars I, t. 1 (CCL 1), Turnhout 1954.

Krystyniacki J. (tłum.), Baron A. Buszewicz E. (oprac.), Jan Chryzostom. Homilie na Ewangelię według św. Mateusza. Część 1 i 2: Homilie 1-40 i 41-90 (ŹMT 18; 23), Kraków 2003.

Kubiak Z., Radożycki J. (tłum.), Józef Flawiusz. Dawne dzieje Izraela, cz. I-II, Warszawa 1993.

Langlamet F., La traversée du Jourdain et les documents de l'Hexateuque, Revue Biblique 79 (1972), s. 7-38.

Marcovich M. (wyd.), Hippolytus. Refutatio omnium haeresium, Berlin 1986.

McDonnell K., Montague G.T., Inicjacja chrześcijańska a chrzest w Duchu Świętym, Kraków 1997.

McDonnell K., Jesus' Baptism in the Jordan, Theological Studies 56 (1995), s. 209-236. 
Mello A., Il passaggio del Giordano, Parole di vita 40/4 (1995), s. 9-12.

Migne J.P. (wyd.), Didymi Alexandrini opera omnia (PG 39), Paris 1863.

Migne J.P. (wyd.), Georgii Pisidae Chronicon Paschale (PG 92), Paris 1865.

Migne J.P. (wyd.), S.P.N. Gregorii episcopi Nysseni opera quae reperiri potuerunt omnia, t. 1-3 (PG 44; 45; 46), Paris 1863.

Moatti-Fine J., La Bible d’Alexandrie, t. 6: Jesus (Josue), Paris 1996.

Monaci Castagno A., Origene. Dizionario: la cultura, il pensiero, le opere, Roma 2000.

Myszor W. (wstęp i przyp.), Ryznar S. (tłum.), Tertulian. Przeciw Marcjonowi (Pisma Starochrześcijańskich Pisarzy 58), Warszawa 1994.

Nazzaro A.V., Simbologia e poesia dell'acqua e del mare in Ambrogio di Milano, Napoli 1997.

Niemirska-Pliszczyńska J. (tłum., wstęp i opr.), Klemens Aleksandryjski. Kobierce zapisków filozoficznych dotyczących prawdziwej wiedzy, Warszawa 1994.

Otranto G., La tipologia di Giosué nel „Dialogo con Trifone ebreo” di Giustino, Augustinianum 15 (1975) nr 1/2, s. 29-48.

Otto E., Gilgal, t. 13, TRE, Berlin - Nowy Jork 1984, s. 268-270.

Pantelia M., Iohannes Chrysostomus. In Jordanem fluvium, w: http://www.documentacatholicaomnia.eu/02g/0345-0407,_Iohannes_Chrysostomus, _In_Jordanem_ fluvium,_MGR.pdf [dostęp: 20.09.2015].

Peckham B., The Composition of Joshua 3-4, The Catholic Biblical Quarterly 46 (1984), s. 413-431.

Penco G., Sulla professione monastica come secondo Battesimo, Rivista Liturgica 47 (1960), s. 34-39.

Piccirillo M., Ainon Sapsafas and Bethabara, w: M. Piccirillo - E. Alliata (red.), The Madaba Map Centenary 1897-1997. Travelling Through the Byzantine Umayyad Period (Studium Biblicum Franciscanum Collectio Maior 40), Jerusalem 1999, s. 218-221.

Pierre M.-J. (wyd. i tłum.), Aphraate. Les Exposés (SC 349), Paris 1988.

Portbarré-Viard de la G.H., Descriptions monumentales et discours sur l'édification chez Paulin de Nole. Le regard et la lumière (epist. 32 et carm. 27 et 28), Leiden-Boston 2006.

Reau L., Iconographie de l'art chrétien, t. 2: Iconographie de la Bible. 1. Ancien Testament, Paris 1956.

Rouët de Journel M. J. (introd. et trad.), Jean Moschus. Le pré spirituel (SC 12), Paris 19473.

Rousseau A. (wstęp, tłum. i przypisy), Irénée de Lyon. Démonstration de la prédication apostolique (SC 406), Paris 1995.

Rubinkiewicz R. (opr. i wstępy), Apokryfy Starego Testamentu (Prymasowska Seria Biblijna) Warszawa 1999.

Ruggiero A. (wyd.), Paolino di Nola. I carmi, Roma 1990.

Salij J., Ksiega Jozuego jako proroctwo, W Drodze 1 (2010) nr 437, s. 117-122.

Saxer V., Heid S., Maria Egiziaca, NDPAC, t. 2, kol. 3055-3056.

Sicre Diaz J.L., Giosuè (Commenti biblici), Roma 2004. 
Słomka J., Wczesnochrześcijańskie nazwy chrztu (Studia i Materiały Wydziału Teologicznego), Katowice 2009.

Spyra M., Elementy teologii chrzcielnej w czwartej i piatej homilii Orygenesa do Księgi Jozuego, Śląskie Studia Historyczno-Teologiczne 19/20 (1986-1987), s. 41-64.

Sulowski J. (tłum.), Stanula E. (wstęp), Święty Augustyn. Objaśnienie Psalmów, z. 1-2 (PSP 37 i 42), Warszawa 1986.

Świderkówna A. (tłum.), Myszor M. (wstęp), Ojcowie Apostolscy, Warszawa 1990.

Szarmach M., Świderkówna A., Sołowianiuk J. (tłum.), Stanula E. (red.), Apologie: Minucjusz Feliks. Oktawiusz; Do Diogeneta; Klemens Aleksandryjski. Zachęta Greków (Pisma Starochrześcijańskich Pisarzy 44), Warszawa 1988.

Taylor J.E., Christians and Holy Places. The Myth of Jewish-Christian Origins, Oxford 1993.

Tov E., The Rewritten Book of Joshua as Found at Qumran and Masada, w: E. Chazon, M.E. Stone (wyd.), Biblical Perspectives, Leiden 1997, s. 233-256.

Tronina A., Jozue - Jezus. Biblijna typologia Zbawiciela, Verbum vitae 1 (2002), s. 41-56.

Turek W., Tertulian (Ojcowie Żywi 15), Kraków 1999.

van Moorsel P.V., Rotswonder of Doortrocht door de Rode Zee, Mededelingen von Het Nederlands Historisch Institut dte Rome 33 (1966) z. 1, s. 59-68.

Vogt E., Die Erzählung vom Jordanübergang, Josue 3-4, Biblica 46 (1965), s. 125-148.

Voicu S.J., Sévérien de Gabala, w: red. M. Viller, Ch. Baumgartner i A. Rayez, Dictionnaire de spiritualité ascétique et mystique: Doctrine et histoire, t. 14, Paris 1990, kol. 752-763.

Waheeb M., The Discovery of Site of St. Mary of Egypt, Amman 2004.

Winling R., Grégoire de Nysse. Discours catéchétique (SC 453), Paris 2000.

Wnętrzak T. (wstęp, tłum. i przypisy), Euzebiusz z Cezarei. Życie Konstantyna (ŹMT 44), Kraków 2007. 